This article was downloaded by: [University of Toronto Libraries]

On: 03 January 2015, At: 13:46

Publisher: Routledge

Informa Ltd Registered in England and Wales Registered Number: 1072954

Registered office: Mortimer House, 37-41 Mortimer Street, London W1T

3J H, UK

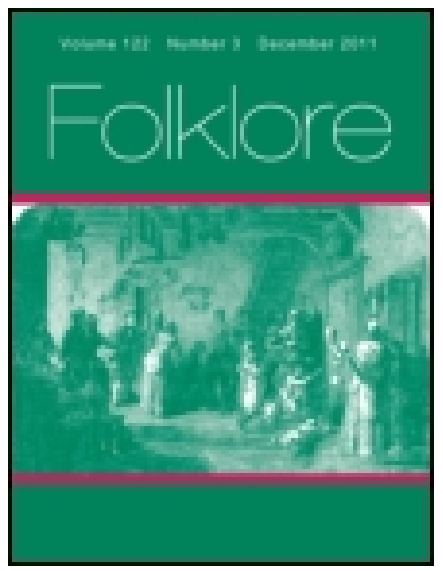

\title{
Folklore
}

Publication details, including instructions for authors and subscription information:

http:// www. tandfonline.com/loi/ rfol20

\section{The Folklore in the Legends of the Panjab}

Lieut-Col. R. C. Temple C.I.E

Published online: 14 Feb 2012.

To cite this article: Lieut-Col. R. C. Temple C.I.E (1899) The Folklore in the Legends of the Panjab, Folklore, 10:4, 384-443, DOI: 10.1080/0015587X.1899.9720510

To link to this article: http:// dx. doi. org/ 10.1080/0015587X.1899.9720510

\section{PLEASE SCROLL DOWN FOR ARTICLE}

Taylor \& Francis makes every effort to ensure the accuracy of all the information (the "Content") contained in the publications on our platform. However, Taylor \& Francis, our agents, and our licensors make no representations or warranties whatsoever as to the accuracy, completeness, or suitability for any purpose of the Content. Any opinions and views expressed in this publication are the opinions and views of the authors, and are not the views of or endorsed by Taylor \& Francis. The accuracy of the Content should not be relied upon and should be independently verified with primary sources of information. Taylor and Francis shall not be liable for any losses, actions, claims, proceedings, demands, costs, expenses, damages, and other liabilities whatsoever or howsoever caused arising directly or indirectly in connection with, in relation to or arising out of the use of the Content.

This article may be used for research, teaching, and private study purposes. Any substantial or systematic reproduction, redistribution, reselling, loan, sub-licensing, systematic supply, or distribution in any form to anyone is 
expressly forbidden. Terms $\&$ Conditions of access and use can be found at http://www.tandfonline.com/page/terms-and-conditions 


\title{
THE FOLKLORE IN THE LEGENDS OF THE PANJAB.
}

\author{
BY LIEUT-COL, R. C. TEMPLE, C.I.H.
}

THESE notes are the outcome of some lectures delivered before the Folk-Lore Society and elsewhere, and have been contributed to this Journal at the request of the President of the Society. But ever since I undertook to discourse on a subject connected with Indian folklore, I have felt that the promise was a rash one, because my official avocations have long been so absorbing and so material in their nature, that I have been unable to keep pace with the advance made of late years in the knowledge of such matters for study as folklore, and I cannot help feeling how much the special investigations of the Folk-Lore Society have gone forward since I last had the honour of addressing it some fourteen years ago, and how little qualified I can now be to show the further way. However, in finally deciding to select one of the few subjects on which I think I may still discourse to good purpose to my more learned colleagues, and throw a useful light on things Indian, I have felt emboldened to discuss it, because, speaking under correction, it does appear to me that English students might make more use than they apparently do of the work of their contemporaries in the British Eastern possessions. So much does it seem to be unknown or ignored that it is quite rarely quoted-even the Encyclopeedia Britannica makes no mention of it-and so I have resolved to bring to notice in some fulness one of five large works with which I might claim a real acquaintance: The Legends of the Panjab, The Devil-Worship of the Tuluvas of South Canara on the Malabar Coast, The Dictionary of Hindustani Proverbs, The Panjab and Indian Notes and Queries, and the folklore in the Indian Antiquary. And I may mention here that this last journal, though scarcely noticed in that of the Folk-Lore Society, has steadily published folklore, acquired at first hand, from its opening volume in 1872 , in a quantity probably surpassing that of the publications of the Society itself. Of the above-mentioned works I have 


\section{The Folklore in the Liegends of the Panjab. 385}

selected The Legends of the Panjab for consideration, because I have had better opportunities of analysing that collection than the others, and not because it is the most prolific as to matters which may be usefully taken up by such a company as the Folk-Lore Society.

In making, therefore, the remarks that are to follow, I ask indulgence if the condensation of statement that is forced upon me is found to be very close, and if the statements themselves are sometimes found to be somewhat behind the times. But in common with all investigators of popular lore, I have found myself face to face with a third difficulty, viz, the best mode of presentation. If one is strictly scientific and arranges the facts in a severe sequence, one is not only apt to be dull, but also to incorrectly interpret the subject, which from its very nature hardly admits of a logical treatment. To begin with, the folk are not consistent and their ideas are all hazy and muddled. Consequently the points of folklore are so far from being clearly separable that they are always mixed up with each other. Any given notion is not traceable to a distinct single basis, but strikes its roots in fact into many, and can often be classified indifferently under any one of several heads. The surest way therefore of projecting oneself into the folk-mind-so far as such a process is possible -is, with the aid of a loose and simple general sequence or classification, to take up the various points as they have seemed to grow one out of the other in folk-logic and processes of thought. This is practically the line that every one who undertakes the exposition of the subject seems to adopt in the end, and I apprehend that it is a procedure that will commend itself to the members of the Folk-Lore Society, which they need hardly be reminded was in its origin and inception a purely literary association.

In order to explain what follows, I should here say that I began to collect the series since partly published as The Legends of the Panjab, somewhat more than twenty years vor, $x$. 
ago, and succeeded in bringing out fifty-nine legends out of one hundred and eighteen collected, at intervals, which in latter years have I fear been very long ones. Now, besides the value of the collection for local historical purposes and for the linguistic forms in which many of them are conveyed, they present a pretty complete view of the machinery of Indian folktales. The extent to which they actually do so can be gauged by experts from the typical tables to be found in the course of my remarks, and drawn up on the lines just indicated; and I would like to say that I belicve that as extensive parallel tables could be made out of the Tuluva Devil-Worship and Hindustani Proverbs, and much completer ones from the Indian Antiquary and from the Indian Notes and Queries, both of my own series and Mr. Crooke's. It is my hope that the tables will bring home to some of my readers what a wide and fruitful tield any given collection of Indian tales affords; how well worth indexing they are for those who seck to get at the roots of the genuine lore of the folk in any portion of the world.

Now the so-called faculties of the human mind, despite their apparenl diversity, are in reality very limited in extent, and are referable to quite a few radical capacities. Those of attention and co-ordination will be found to cover most of the others that have names. Thus memory and observation are both referable to attention, and so are mathematics, logic, and grammar to co-ordination. Indeed mankind, though unaware of it, talks mathematically, for the facts of speech can be actually stated clearly in terms of mathematics. And now when tracing the ideas of folklore by apparently natural processes to their roots, I soon found myself harking back to grammar with the main divisions of subject and predicate; the matter to talk about and the conversation thereon. The "subject" divides itself into the hero and heroine, and the "predicate" into the commencement, the incidents, and the conclusion. But here all approach to 


\section{The Folklore in the Legends of the Panjab. 387}

clear division stops, and although the heroes are classed as natural and supernatural, and the heroines are considered according to qualities and peculiarities, and although the sub-heads under each of these are very numerous, it must be understood that they have been placed just as has been found convenient, that a very different disposition would probably be equally correct, and that most of the items can fairly occupy places under several heads.

Having thus explained my procedure and methods, I now give the tables themselves.

\section{SUBJECT.}

(i.) Hero.

A. Natural.

I. Miraculous conception and birth.

(a) Remarkable pregnancy of mother.

2. Substituted child.

3. Predestined child.

(a) Avenging hero.

(b) Iniprisoned hero.

4. Calumniated child.

5. Acts and endowments.

6. Identification.

(a) Signs of the coming hero.

(b) Fulfilment of prophecy.

7. Companions, human and animal.
(a) Unrequited faithfulness.
(b) Community of birth.

8. Sons.

(a) Nostrums for procuring sons.

\section{B. Supernatural.}

x. Immortality.
(a) Reappearance.
(b) Saints.
(c) Ghosts.
(d) Spirlts.
(e) Gods.
(f) Godlings.
(g) Warriors (bfrs).
(h) Demons and devils.
(i.) Anxorcism.

2. Second sight.

3. Miracles.

(1.) Miractes by proxy.

(b) Restoration to life. (c) Restoration to health.
(i.) Cures.

(ii.) Bonefits.

(1) Sons.

(2) Rain.

(d) Inexhaustible supplies.
(1.) Voracity oxtraordi. nary.

(c) Miracles for injury.

\section{(i.) Curses. \\ (ii.) Nightmaros.}

(f) Stock miracles.

(g) Native view of miracles.

(h) Secret miracles.

4. Magic versus Miracles.

(a) Sympathetic magic. 
388 The Folklore in the Legends of the Panjab.

B. Supernatural-continued.

(i.) Effigies.

(ii.) Cerentonial canni. balism.

(iii.) Life-index.

(I) Life-token.

(2) Token-trees.

5. Enchantments.

(a) Prophylactic charms. (i.) Snakebile.

6. Prayer.

(a) Faith.

7. Invocation.

(a) Summoning the absent.

8. Propitiation.
(a) By abuse.
(b) Ofrerings.
(c) Libation.
(d) Ceremonial generosity.

(i.) Charily.

(ii.) Alms.

(I) Self sacrifice.

(e) Sacrifice.

(i.) Ascaticism.

(ii.) Penance.

(iii.) Austerity.

(iv.) Slavery for debt.

(f) Vows and oaths.

(i.) Ceremonial oaths.

(1) Antidotea.

(ii.) Vowing and swaring thrice.

9. Prophecy.

zo. Metamorphosis.

(a) Disguise.

(i.) Change of skin.

I. Metempsychosis.

(a) Sati.

2a. Counterparts of saints.
(a) Iragiolatry.
(b) Demons.
(c) Godlings.
(d) Ogres.

(e) Giants.

(f) Sea-monsters.

(g) Mermaids.

(h) Serpents.

(i.) Characteristics and powers.

(ii.) Miracles.

(iii.) Origin.

13. Anthropomorphosis.

(a) Ilumanised animals.
(i.) Talking.
(ii.) Grateful.
(iii.) Revenge/ul.

(b) IIumanised things.

(i.) Talking.

(ii.) Enchanted things.
(i) Circles.
(2) Lines.
(3) Necklaces.
(4) Rotariea.
(5) Arma.
(6) Magic numbers.
(7) Holy water.
(a) Blood.
(B) Milk.
(y) Ambrosia (amrita.)
(b) Sacredness of water.

(8) Miraculous vehicie.
(a) Heroic leap.
(B) Flying through the air.
(y) Wingad animals.
(y) Winged things.
(a) Migrating images and rombs:

(9) Magic music.

(a) Magic insuruments.

(10) Hair and ite powers.

(*) Sacredness of the beard.

(II) Invisibility.

(12) Procedure for enchantment.

(13) Priesto.

(*) Possassion.

(A) Exorcism, 
The Folklore in the Legends of the Panjab. $3^{89}$

\section{SUBdECT.}

\section{(II.) Heroine. \\ A. Quallties.}

3. Counterpart of hero.

2. Native view of women.

3. Tabu.

4. Characteristics.

(a) Delicacy.

(b) Attraction.

5. Identification.

6. Beneficent heroines.

(a) Fairies,

(i.) Celestial messengers.

(ii.) Foreign brides.

7. Maleficent heroines.

(a) Calumniators. (b) Co-wives.

(c) Stepmothers in poly. gamy.

(d) Witches.

(i.) Wise-zumen.

(i) Powern.

(2) Attributes.

(e) Ogress.

(s) Serpent-heroine.

8. Foundling.

(a) $\mathrm{Egg}$-heroine.

(b) Sleeping beauty.

(i.) Fortign or irregular brides.

\section{B. Pecullaritles.}

I. Chastity.

2. Virtue.
(a) Male versus female.
(b) The zone, male and female.

3. Maintenance of virtue.

4. Ordeals.

(a) Testa for identification. (iil) Signs of royalty and saintship.

(iii.) Pilgrimage-stamps.

(b) Impossible task.

(i.) Swayamvara.

(ii.) Ridalles.

(I) Symbolical opeech.

(iii.) Caremonial gambling.

\section{Predicate.}

\section{A. Commenoement.}

I. Seeking fortune,

2. Oracles.

3. Prophecy.

(a) Fortune-telling,

(b) IIoroscopes.

4. Fate.

(a) Preordination.

(b) Decree of tate.
5. Prophetic dreams.
(a) Interpretation.

6. Augury.
(a) Divination.
(b) Omens.

7. Luck.
(a) Actions,
(b) Times.
(c) Astrology. 
390 The Folklore in the Legends of the Panjab.

A. Commencement-continued.

8. III luck.

(a) Misfortune.

(b) Sin.

(i.) Widows.

(ii.) Ceremonial uncleanness.

(1) Leprosy.

(2) Treatment of lepera.

(iii.) Female infanticide.

(iv.) Expiation.

(v.) Murification.

(1) Ceremonial bathing.

\section{B. Inoidents.}

I. Jewels.

(a) Origin of jewels.

(i.) Kubies.

(ii.) Rearls.

(b) Flowers.

(c) Laughter, tears, and speech.

2. Tricks.

3. Ceremonies.

(a) Marriage.

(i.) Betrothal.

(b) Adoption.

(c) Inheritance.

(d) Divination.

(e) Initiation.

(1.) Earboring.

(f) Mourning.

(g) Conveptional,

(i.) Challange.

(ii.) Disgraca.
4. Domestic customs.

5. Beliefs,
(a) Animals.
(b) Celestial bodies.
(c) Eclipses.
(d) The human body.
(e) The deluge.
(f) The Deily.

6. Customs based on beliefs.

(a) Aspect of shrines.

(b) Refuge.

(i.) Sanciuary.

(ii.) Asylum.

(iii.) Hospitality.

(c) Calling by name.

(d) Releasing prisonerg.

(e) Cerenonial umbreltas.

(i.) Signs of alignity.

\section{o. Conolusion.}

I. Poetical justice.

2. Vengeance.

(a) Punishment.

(i.) Torture. (b) Ceremonial sujcide.

(i.) Salf-immolation.

(c) Stock punishments.

We are now in a position to tackle the multifarious details of my subject with some chance of arriving at definite ideas, even though the extent of the materials obliges me to be brief almost to baldness. First of all, it will be perceived that the typical hero is born on an auspicious day by various 
forms of miraculous conception or impregnation, and that his mother experiences a miraculous or at least a remarkable term of pregnancy. He is a substituted child, in one instance, by an accident which curiously brings out an allusion to an old custom of registering princely births, and in another by his own act, as a mode of magnanimous selfsacrifice. Now, substitution of children in folktales is usually an act of malice, and its artribution to a mere chance occurrence is, so far as I know, a novel feature. He is a child of predestination, fated in one case to slay the ogre who is to devour his hostess's son, the ogre being aware of the predestination. In such case he would appear to be a variant of the avenging hero, pre-ordained to set right what is wrong in this world, a belief common apparently to the whole world of religious notion. As regards this last idea, the form it usually assumes in this collection is the common one of predestination to kill his own parents, who try as usual to avert their fate by imprisoning their uncanny offspring in a pit, necessarily to no purpose. He is the victim of calumny everywhere, the stock cause being jealousy or ill-will begotten of unrequited love. Versions of Potiphar's Wife are common in Indian and all Oriental folklore. He of course assists the grateful animal to his own subsequent advantage, and obtains access to the heroine by disguising himself as her husband with success. He is endowed with extraordinary and impossible strength or skill. His identification is almost always due to miraculous intervention of some sort; and we have more than one instance of the corollary to that idea in the signs of the coming hero with which he has to comply, a notion not far removed from that of fulfilment of prophecy. The "signs" are in themselves, however, as might be expected, childish and not very dignified.

The hero has companions of the conventional sorts, human beings, beasts, birds, and insects, who talk to him and assist him in his diffculties. His human companions, however, 


\section{The Folklore in the Legends of the Panjab.}

sometimes desert him in his times of difficulty, a situation apparently introduced to enhance the glory of the hero himself, while his animal companions undergo at times the fate of Gelert, and are killed for their endeavours on behalf of their masters, an incident well known to Indian and other folklore generally. Accidental community of birth is a common and perhaps natural characteristic of the hero's companions everywhere. The hero and his horse or his constant friend are frequently described as having been born at the same place and hour. It is to be expected that a chance of this kind should attract the popular attention and lead to an assumption of community of fate in the beings so circumstanced.

Perhaps the most decply engrained superstition of all among the Indian populations is the necessity of having a son, as the surest means to salvation; and there is no subject in Indian folklore of more universal occurrence than that of the miraculously and fortunately born hero-son and his doings. There is no point upon which folktales more frequently turn. The hold that the desire of a son to succeed has on the people is more than once powerfully indicated in the Legends, and women are described as deliberately introducing a co-wife into their homes to secure it. There can be no doubt as to the strength of a desire, when it brings about such an action as that. A desire so universal, so strong, so important to the peasantry necessarily finds not only frequent expression in their stories and legends, but also in the acts of daily life, sometimes of a very serious nature. Women have over and over again been guilty of murder and incendiarism due to wild superstitious attempts to gratify it. I can recall a case in which the ignorant low-class mother of daughters only has, with the assistance of her elder daughter, killed a little girl belonging to a neighbour, by way of human sacrifice to the supernatural powers to procure her a son at the next continement, and a case in which a barren woman of the 
superior peasantry set fire to a neighbour's dwelling with the same view.

The whole category of nostrums known to Indian folkwisdom, and it is a very wide one, is employed by those who are so unhappy as to be barren or son-less, to avert or overcome the misfortune. Every kind of supernatural being, god, godling, hero, saint, wise-woman, wizard, demon, devil, ogre, exorcist, and the like can grant or procure sons. The faith in the givers and the power to give is boundless and ineradicable, going back to the dawn almost of Indian folklore. But, astonishingly varied as are the nostrums tried, the oldest and still the favourite in story is the giving of something to eat to the would-be motherflowers, fruit, rice, grains, seeds, and so on. Prayer and saintly intercession are also common in the Legends, mare or less consciously introduced for the glorification of high places; and of course holy wells, pools, tanks, shrines, tombs, graves, and other spots, out of which money can be made by way of fees, are notorious for fulfilling the wishes of the disappointed.

Sons born in response to vows, intercession, faith in nostrums, intervention of holy personages, and so forth, are almost always heroes, ushered into the world with the customary portents and acting in the ordinarily heroic manner. It is only, therefore, by considering what the possession of sons means to a native of India that one can grasp the full import to an Indian audience of such a story as that of the Baloch hero, Jaro, in the Mir Chakur legend, who slew his two sons in fulfilment of a rash vow.

Apart from, though closely connected with, purely imaginary heroes, or beings round whom a mass of myth has collected, by far the most important class of popular heroes in North India are the saints and holy personages, Hindu and Muhammadan. The holy man, godling, or saint of Northern India is precisely the demon or devil (bhuta) of South India. There is at bottom no difference between 


\section{The Folklore in the Legends of the Panjab.}

any of them, and the stories about them are hopelessly mingled together. Be his origin Hindu or Muhammadan or merely animistic, the saintly or demoniacal, i.e. supernatural, hero's attributes, powers, characteristics, actions, and life-history are in Indian folklore always of the same kind and referable to the same fundamental ideas. He does not belong to any particular form of creed or religion, but to that universal animism which underlies the religious feeling of all the Indian peasantry. I can see no radical difference in the popular conception of the Hindu Guru Gorakhnath or the Muhammadan Sakhi Sarwar of the North, and the animistic Koti and Channayya of the South. The peculiarities of any one of them are proper to them all. They are best studied as a whole.

In the Legends holy personages play a larger and more important part than the Rajas or secular heroes themselves, and their characteristics and the notions about them are well displayed. Thus, in the quaint tales that have gathered round the memory of the Saints of Jalandhar, we find an account of the struggle for local supremacy between a Musalman saint and his rival and counterpart, a Hindu jogi; and the point for the present purpose is that the characteristics and the powers of the pair are represented as being precisely the same: they both belong to the same class of supernaturally endowed beings, and the result of the contest clearly hinges on the sectarial proclivities of the narrator of the story.

Immortality and reappearance, ideas apparently common to the whole human race, are widely spread attributes of Indian holy men, the title of Saint Apparent (Zahir Pir) being by no means limited to the mixed Ilindu-Musalman canonised warrior Guru Gugga; and in these pages we have a case in which the opposing saintly personages, Hindu and Musalman, on both sides of a sectarian struggle, kill each other and all become living, i.e. immortal, saints (jiute pir). But in other matters than immortality we find 
that the gods and saintly heroes are much mixed up, and naturally, in popular conception; and we have more than one instance in which the special attributes of the Deity, even from the Hindu standpoint, are ascribed to such personages-or ought we to say, more accurately, such abstractions ?-as Guru Gorakhnath. And vice versâ, even such gods par excellence as Siva and Parbati are reduced almost to the level of ordinary mortals.

In connection with the belief in immortality, that pathetic hope of the incapacity of a whole personality for death, so universal in mankind, we find that saints, especially deceased saints, are much mixed up in Indian idea with ghosts and spirits. In this form they have the power of appearance peculiar to ghosts all the world over, particularly at midnight-" midnight the time for saints, adht rdt Pirdn $d \hat{d}$ veld"-is an expression that occurs more than once. They appear also in dreams, sometimes I rather suspect with a view to helping the progress of the story.

A careful study of the instances in which beings endowed with immortality, i.e. ghosts and spirits on the one hand, and gods, godlings, and warriors (birs) on the other, appear in the Legends, and of their actions as recorded therein, will afford yet another proof that fundamentally there is no individual difference between them in the popular conception, nor between them and their mortal counterparts, the holy personages of all sorts. They all, the mortal and the immortal, do the same things, have the same characteristics and powers, and are introduced into folktales for the same purposes. The differences to be observed in titles and attributes is due to an overlaying, a mere veneer, of rival religious philosophies-thus, where ghosts and spirits appear the tale will be found to be Muhammadan in origin or form, where gods, godlings, and warriors appear it will similarly be found to be Hindu in origin or form. Where the tale refers back to days before set Hinduism, or has its origin in an anti-Hindu form of belief, or is given an anti-Hindu cast, 


\section{The Folklore in the Legends of the Panjab.}

the appearance will be demoniacal or animistic. In every case they will belong to one fundamental category and be essentially animistic heroes, or they may with equal truth be classed as saints minus the veneer of Musalman, i.e. Western, philosophy.

The corollary to the notion of ghosts and spirits, exorcism and the casting out of devils, only once occurs in the Legends, though miraculous and magical cures of all other sorts abound, and then only by a reference, which is, however, a significant one. For there a Hindu jogi cures a Muhammadan family of goblins and spirits by medicines and herbs; and it is to be observed that in the passage in question the goblins were Musalman ( $j i n n$ ) and the spirits were Hindu (bhut).

Perhaps the most strongly marked variant of the idea of immortality to be found in Indian belief is the very common folktale expedient of temporary death. In the Legends there is a distinct instance of it, and also a matter-of-fact allusion to it, made in terms that clearly show the universality of the acceptance of the notion.

Supernatural personages in Indian story have as a matter of course, in common with many otherwise work-aday mortals, the power of second sight-that knowledge of things that are hidden-and, in addition to forestalling secret malice, proving innocence "not proven," and so on, can detect unseen thieves, a power by the way claimed by certain leaders of theosophy and esoteric Buddhism who ought to know better.

Supernatural personages may also be said to possess certain inherent powers, of which that of working miracles is the most important. So much are miraculous powers inherent in saints that saintship is held to be proved by the possession of the wonder-working gifts, and it is not an offence to holy men to seek to test them. Every one in contact with a saint is considered to be justified in doing so. These powers can be delegated, and we find several 


\section{The Folklore in the Legends of the Panjab. 397}

instances of miracles performed through an agent, by proxy as it were. The agency need not be necessarily that of a supernatural or human being. Things dedicated or sacred or appertaining to a saint are sufficient for the purpose, as when a fountain or well sacred to a saint will effect a cure, or when his flute, or conch, or horse, or other animate or inanimate thing belonging to him, will procure for him even a passing desire. The miracles effected at tombs and shrines belong to this class, and these are ubiquitous in India generally, their universality giving form to the widely-spread and pretty notion of the lover miraculously disappearing alive into the tomb of the dead and buried beloved.

By assuming the power of working miracles to be an attribute of saints, one becomes prepared for their being able to do anything that is necessary for their own personal glory, the protection of themselves and their followers, or the exigencies of the tales about them. But even then one is sometimes taken aback at the ingenuity of the storytellers, e.g., causing the gods to cash a document that corresponds to a cheque is one bright idea, and carrying a tiger up his sleeve to terrify the ruler of the period is another. Both are attributed to well-known saints. But the very quaintest, and in some respects the most remarkable and instructive tale I have ever come across of an Indian miracle, is one arising out of the well-known scientific and astronomical proclivities of the celebrated Raja Jai Singh Sawai of Jaipur, who flourished only one hundred and fifty years ago, and to be found in the Legends. According to this tale the populace believe that not only could he make a moon, but that he had a private moon of his own to light up his city on dark nights.

It is obviously necessary to the greatness of the saints, indeed to the very success of the shrines, on the proceeds of which the bards and story-tellers live, that holy men should be able to protect themselves and their followers; and the varieties of ways in which they are fabled to be 


\section{$39^{8}$ The Folklore in the Legends of the Panjab.}

able to do this is surprisingly large. They can of course go unharmed through ordeals by fire, and can starve without injury. They can make themselves invulnerable by arrows, rocks, bullets, daggers, and what not, and can burst their fetters. They cannot be hanged, and can control and tame animals and slay them with ease. Even for matters of mere personal advantage and comfort they effect miracles. In one place the hero opens locked doors without keys in order to get at his mistress, illegitimately by the way; after which one is somewhat surprised to learn in the Legends that it is wrong to work miracles for inadequate objects or for the mere pleasure of the thing. But the favourite miracle of the creation of a crowd of followers or wild beasts as a means of protection in a difficulty is probably an extension of that idea of invisible supernatural assistance in all severe struggles that has taken so strong a hold on the popular imagination all over the world. And this leads to the consideration that in the study of the actual miracles attributed to saints and the like it is something more than merely interesting to observe how much they follow the general nutions of the people as exhibited in their folktales, how much they are based on folklore, how much on the desires and aspiration of the folk themselves. Thus we may class as belonging to the idea of immortality and its corollaries the frequently recurring miracles of restoration to life, the vivification of an idol, and the curious instances of a childsaint making a wooden horse run about and a wall into a hobby-horse when in want of a plaything. The restoration to the original form and life of human ashes, of a devoured bride and bridegroum, of an eaten horse and kid, are but extravagant extensions of the same idea. So also without the extravagance are the restoration to greenness and life of a dried-up garden, a dead tree, a withered forest. The odd miracles of making the dub-grass evergreen and fruit-trees to bear fruit out of season are further developments of the main idea. 


\section{The Folklore in the Legend's of the Panjab. 399}

From restoration to life it is not a far cry to restoration to health, and as might be expected miraculous cures abound in these pages and may almost be considered to be the stock in trade of a saint. With restoration to health I should be inclined to connect the bringing about of blessings and good fortune, the fulfilment of desires, the grant of assistance of every kind, especially in the case of followers and supporters. Saints are of course conspicuous for the power, directly or indirectly, to grant the most prominent of all the desires of the Indian peasantry, i.e. sons to succeed them. This occurs again and again in the Legends, but instances are also found of the grant of promotion and high position in life. With these must also be classed the great "blessing" of a rural peasantry, the bringing of rain, and the chief desires of seafarers, a fair wind and immunity from drowning. Saints can accordingly do all these things. In a land of great and dangerous rivers, like the Panjab, ferries and the crossing of rivers occupy a prominent place in the life of the people; and so we find a saint making a boat out of his begging-gourd and an oar out of his staff when in a hurry to cross a stream, the form of this particular miracle being attributable to the universal belief in the miraculous vehicle.

Riches, including a plentiful supply of food, and assistance in procuring them, are largely desired everywhere; and so we have saints finding hidden treasure, turning all sorts of things into gold, and producing jewels and jewellery. We also find them making the sun to broil fish for themselves, and supplying followers with miraculous food. But cupidity demands much more than the mere supply of necessities, and the narrators of the stories about saints have had to cater to this failing of human nature. Hence the miraculous production of inexhaustible treasure and inexhaustible supplies of food, the inexhaustible bags, the stories of "loaves and fishes," and such like, the finding of hidden treasure and the creation of gold and jewels and of all sorts of unlikely objects, even out of a praying-carpet. From an 


\section{The Folklore in the Legends of the Panjab.}

in exhaustible supply to an inexhaustible capacity for ahsorbing it is a natural step; and so we find voracity extraordinary in many a quaint form to be a common capacity of heroes, gods, and ogres alike ; indeed, of the last, as the enemy of the heroic tribe, it is the usual attribute or sign.

In opposition to the beneficent powers the converse powers to destroy life or inflict injury in an extraordinary way naturally appear in many an ingenious form; and with these may be classed the great family of saintly curses and nightmares or terrifying dreams. "He that can help can also injure," "the Lord giveth and the Lord taketh away," are propositions involved in the glorification of every kind of hero. They are constantly brought forward in the Legends with as much emphasis as possible, the saints helping and injuring, giving and taking away and giving back again almost in the same breath. Precisely as blessings can be conferred vicariously, so can injuries be similarly inflicted; and as a consequence of this idea a town fire is attributed to the fettering of a saint by its ruler. And lastly, just as it is necessary for the bards and singers to glorify the saints, and to inculcate a sense of their power for mischief, so it is also necessary, since bards are usually attached to particular saints, to maintain their individuality. Hence the peculiar habit of attributing stock miracles to certain saints. To explain: Dhanna, the Bhagat, is always connected with the story of making a god out of a stone; Rode Shah with the wall-known greenness of the $d u b$-grass in the dry weather; Guru Gugga with speaking from his mother's womb; Sakhi Sarwar with several performed at his shrine; and Gorakhnath with a whole string of them performed in "the Land of Karu."

The very large number of miracles that occur in the stories of saints, universally common as these stories themselves are, is due to the attitude of the native mind everywhere towards the marvellous. A miracle in India does not excite much wonder, and is to some extent looked upon as a 


\section{The Folklore in the Legend's of the Panjab. 401}

natural incident in everyday life. Miracles are always occurring; every village has instances of them; everyone has knowledge of some that are notoriously within the experience of acquaintances. Even Europeans can hardly become intimate with the thoughts and customs of native neighbours without being cognisant of supposed miraculous occurrences around them. They are frequently believed to have happened to Europeans themselves. Sir Henry Lawrence is thus believed at Firozpur in the Panjab to have been compelled to compliance with a saint's behests by terrifying occurrences, induced by the saint during sleep. Almost precisely the same story has been current in the Ambala Cantonment about myself; and I have also conversed with the son of the child supposed to have been raised from the dead by the long deceased saint, Sakhi Sarwar, for Dani Jatti, now the heroine of a popular Panjabi Legend widely sung all over that Province. That personage and his neighbourhood had no sort of doubt as to the truth of the tale about his father and grandmother. It would never have occurred to them to doubt it. The once notorious Ram Singh Kuka, whom the present speaker knew personally while a political prisoner in consequence of his raising a petty religious rebellion against the British Crown, was credited with miraculously lengthening the beam of a house for a follower at Firozpur, by way of helping him to preserve his property. This beam was shown to me in all good faith within ten years of the date of the supposed miracle. Such being the conditions, one can hardly be surprised at what has been noted on the subject of the miraculous doings of saints and holy personages.

So far we have been dealing with miracles, whose value lies in their publicity; but the bards and tellers of the marvellous stories have by no means overlooked the im. portance to them, as a means of turning the popular imagination to their own benefit, of hidden or undisclosed miracles. In the Legends, among the tales that have vol. $x$. 


\section{The Folklore in the Legends of the Panjab.}

gathered round the Saints of Jalandhar, we are specially treated to a relation of the "open and secret miracles of Sufi Ahmad of Jalandhar," and of the severe physical punishment of a woman for disclosing a secret miracle of another Jalandhar saint. In other instances, disease, and even hereditary madness, are attributed to divulgence of miracles secretly performed. Now, when one thinks over the enormous influence that the idea of ability to perform miracles secretly could be made to wield over the minds of a credulous and ignorant population, one wonders indeed that it does not more frequently crop up in Indian folklore; unless its occurrence is to be regarded as an outgrowth of the idea of the punishment of idle curiosity so common in all folklore -the tales of Bluebeard's wives and so on-which again may perhaps be held to rest on the notion of tabu.

Miracles may be defined as wonders legitimately performed, while magic embraces the class of illegitimate wonders. The actual deeds, whether the result of miraculous powers or magical arts, seem to be much the same, and in India to be performed for much the same objects. The difference is that the one is right and holy, and the other is wrong and unholy. It is good to work marvels miraculously, but very bad to arrive at the same result by magic. And as, in the bard's eyes at any rate, all heroes, saintly or secular, are personages to be reverenced, one is not astonished at the very small part that magic is made to play in the Legends. Indeed, one scarcely ever sees it put forward as a mode of producing the innumerable marvels related. Magic is, however, distinctly attributed in one instance to a daugliter of the Serpents, but only for the purpose of moving a heavy stone, an object which, in the case of a saint, would be related to have been achieved by a miracle. It is as distinctly attributed in another instance to Gorakhnath, in circumstances where a miracle would seem to have been more appropriate, and in the miclst of a host of miracles related of this great saint or holy man. Indeed, in this last 


\section{The Folklore in the Legends of the Panjab. 403}

case the bard would seem to have confused the notions of miraculous and magical powers.

Of what is generally known as sympathetic magic, and may be nothing more than an extension of the notion of the delegated miracle, and so merely a cure by proxy, there is a strong instance in the Legend of Raja Dhol, where the injured leg of a valuable camel is cured by firing that of a stray ass. Restoration to life and health, i.e. cures, and their opposites, destruction and injury by effigy, are strictly extensions of the same idea.

Now, when a belief becomes rooted in the popular mind, a custom, however barbarous and disgusting, is sure to be based on it, and the apparently harmless notion of sympathetic magic has led in India, and many other lands, to the horrible custom of ceremonial cannibalism. In the Legends we have distinct proofs of this, where fagirs eat up the body of a famous leech in order to obtain his curative powers, and Baloch heroes make roast meat of an enemy's ribs in order to absorb his "virtue," i.e. fighting strength,

A barmless phase in the belief in sympathetic magic, leading to many a pretty and fanciful custom of the folk, is to be seen in a form which I have always flattered myself I discovered, when writing the notes to Wide-awake Stories a good many years ago, and then called by me the Lifeindex. It now scems to have found a definite place among the recognised technicalities of writers on folklore under the guise of the Life-token. In the Legends, however, we do not hear much of $i t$, except in an allusion to the custom of presenting a female infant to the hero as a bride, together with a mango seedling. When the tree fruits the girl will be twelve years old at least, i.e. marriageable. It is evidently felt here in a dim way that the tree is somehow or other her life-token. This custom may be of more interest to ourselves than at first appears, because the habit of planting trees, fruit-trees especially, to commemorate the birth of children, or of connecting certain trees with indi- 


\section{The Folklore in the Legends of the Panjab.}

vidual children in a family, is common enough in England. It has occurred in fact in the present writer's own family, where the trees dedicated to himself and his contemporaries are still standing at the ancestral family home. It is possible, therefore, that the custom of what we may now call token-trees, the world-wide habit of planting trees to commemorate local and even general events of striking importance, such as the Revolution Elms just outside the ancestral home above mentioned, and many a famous oak and ash and yew one can readily call to mind, partly has its roots in the fundamental idea of sympathetic magic.

The existence of miraculous and magical powers presumes the existence of recognised-or may we call them orthodox?-processes for producing miracles and magic, opening up the wide subject of charms. But of these, as matters too well known to require explanation, there is not much detail in the Legends, apart from that necessary to briefly explain the miraculous acts themselves; and such as occurs is confined to that all-important division of the subject in the eyes of a superstitious peasantry of prophylactic charms. The importance of these to the people is further emphasised by the fact that when charms are mentioned it is, in every case but one, for the prevention or cure of snakebite, perhaps the greatest dread of all of the Indian peasant, a situation in which he probably feels more helpless and more inclined to invoke supernatural aid than in any other. Such charms are indeed so much mixed up with miracles proper as to form in reality a variety of miraculous cures. Besides charms against snakebite, there are mentioned some as cxisting against sorcerers, i.e. the charmers themselves; and among real prophylactic charms against general bodily harm, only the wearing of the sacred tulsi (sweet basil) beads occurs.

The absence of detailed accounts of charms and of the performances of exorcists must not, as above hinted, be taken as implying their scarcity, or only a languid interest 


\section{The Folklore in the Legends of the Panjab. 405}

in them among the population; and perhaps the best indication of the facts being the reverse of such a presumption is to be found in the Legends themselves, in the so-called "genealogies" of Lal Beg, the eponymous saint or hero of that curious sect of the scavengers, which may be said to have set up a religion and ritual of its own, though that is in reality an eclectic hagiolatry derived from every superstition or faith with which its members have come in contact. Now the ritual, where it does not purport to relate the genealogy of the hero, consists chiefly of a string of charms of the common popular sort.

Supernatural intervention in the affairs of mankind, as the result of vicarious prayer and intercession, is, one need hardly say, a universal and deeply-cherished human belief; and it is not by any means always claimed in the Legends that saints or saintly heroes effect their assisting or injuring wonders direct. Prayer is, in fact, in common request as an agent for the performance of miracles, and some quaint stories regarding it are to be found in the Legends. It is there usually, but not of course always, addressed to God by both Muhammadans and Hindus by that mixing up of the rival religions so typical of the natives of India.

From invoking the aid to invoking the presence of the supernatural and invisible protector is but a small step; and the notion of prayer leads straight on to that of invocation -that summoning of the absent so common in folktales, usually to help on the story. It is necessarily a most widely-spread notion, appertaining to the religion of the folk all the world over, and the means employed for it are everywhere very varied. The story in the Legends of the use of holy water for the purpose in the Panjab has a European ring about it. As saints may be invoked by their followers, so can they in their turn invoke others; sometimes by mere will power; sometimes by a direct summons in everyday use, such as clapping the hands; 


\section{The Folklore in the Legends of the Panjab.}

sometimes by one of the stock devices for summoning the absent employed in folktales.

Now saints and all the supernatural powers that be can injure as well as aid, can curse as well as bless; and beings that can injure need propitiation. So we find offerings made to the saints without reference to the faith or creed of either giver or receiver, such as milk, the most important beverage of all in the Panjab, precisely as it is offered to Mother Earth. At the same time we have a remarkable instance of propitiation by abuse in the story of Puran Bhagat, where a woman deliberately abuses and curses her patron saint, with the avowed object of extoring favours from him. This notion, though somewhat startling, is widely spread. Propitiation is naturally usually prescriptive, i.e. it is usually employed towards one special protector or class of protectors; but it as naturally constantly loses that character, and becomes general and even vicarious; as when the heroine pours out libations first to the God of the Waters and then to the birds and beasts, an act of general charity likely to be welcome to the gods.

In close connection with the notion of general or promiscuous propitiation, there is a variety of terms in the vernaculars, which are usually translated by "alms-giving, generosity, charity," and so on; but their real import is the making of propitiatory gifts or offerings to saints and priestly or holy personages. Generosity in the East does not convey the idea of lavishness in gifts generally, but in gifts to saints or priests. In this sense it is perhaps the most largely extolled virtue of all in fable and story, and of set purpose. This universal inculcation of the virtue of what may be called ceremonial generosity does not arise altogether out of any superstitious, religious, or folklore custom, but out of the necessities of the bards and the tellers of tales about saints. Shrines and their attendants have to be supported and means must be gathered to support them; 


\section{The Folklore in the Legends of the Panjab. 407}

and hence the very high praise and the very great supernatural and future rewards offered to the "generous," which are not confined to any particular creed or country. The Indian saint, and after him the attendants and hangerson at his shrine, live on alms; and so "charity" and "generosity" on the part of their adherents and audiences are "virtues" that naturally loom very largely in their tales and poems. The ceremonial nature of the "generosity" comes out in the fact that the gifts to be efficacious must be of the conventional sort; and we have repeated instances in the Legends of the wrong kind of alms being refused by saints and holy men, however valuable and lavish.

It is obviously necessary, when dwelling on the importance of such a virtue on behalf of a hero, that the hero him. self should not be represented as being wanting therein; and hence "generosity" is an invariable attribute of the saints. Every saint has been wildly and extravagantly generous, whatever else he may have been. Sakhi Sarwar, Shams Tabrez, and the rest of them are all heroes of generosity. So also on the other hand are the folk-heroes Hari Chand and Raja Amba, while the Baloches have a special hero of their own, Nodhbandagh the Gold-scatterer. The extravagance of the acts of generosity attributed to saints and holy men is boundless. Self-mutilation and self-blinding to gain sinall objects are among them, stretched in more than one notorious instance into the impossible feat of striking off his own head as alms. Extreme self-sacrifice of this kind assumes a curious form, when a jogi is credited with ceremonial cannibalism, in allusion, perhaps, to the well-known real or attributed habits of the $A$ ghori faqirs.

Offerings of all sorts, and under whatever name, involve the giving up of something, if of value to the giver the better. A notion that has universally led to such concrete ceremonies as sacrifices of all kinds of things of both material value, like cattle, and of purely ceremonial value, like the blood spilt in a notable fight detailed in the Legends. . All 


\section{The Folklore in the Legends of the Panjab.}

these things are, however, the giving up of something outside the self, however valued or appreciated, and the idea can be easily extended to the yet greater virtue of the giving up of something that is within or part of the self. It has actually been so extended all over the world in the forms of asceticism and penance, and nowhere more recklessly and intensely, more wildly in fact, than in India. The virtues of austerity and expiatory self-sacrifice are most carefully extolled and inculcated throughout Indian folklore and in the Legends, and have led there and elsewhere to one practical result in the widely-spread custom of voluntary slavery for debt not only of self but of wife and children.

Gifts, offerings, sacrifices, penances, and the like may be called practical propitiation; but several ways of reaching the same desirable goal supernaturally have been evolved by the superstitious peasantry of India, and the rest of the world too for that matter. Vows, i.e. promises to reward the supernatural powers invoked for acceding to prayers, and oaths, i.e. invocations to the same powers to witness the promises, are two prominent methods of propitiating the all-powerful inhabitants of the unseen world, constantly in every language and in every national mind mixed up with each other. In the Legends we have the whole story of the idea: oaths which are vows and vows which are oaths, notices of the advantages of performing vows and oaths, the importance of keeping them, and the terrible penalties attached to their breach, especially if made to a deceased saint, or a shrine in which a bard is personally interested. A variant of the terrible tale of Jephthah's Daughter is to be found in the Legends.

In every case where it goes beyond being a mere invocation to the supernatural powers the taking of an oath involves a ceremony deriving from the superstitions of the takers; and the ceremonies connected with the taking of oaths are therefore not only interesting but nearly always valuable to the student. They are also varied to a limitless extent, and are 


\section{The Folklore in the Legends of the Panjab. 409}

a strong indication of the objects held to be sacred in any given form of belief, e.g., swearing by touching the sacred thread ( $j a n e u$ ), or by tearing the thread off a cow's neck by a Hindu, by touching the Quran by Muhammadans or the Bible by Christians, are sure references to things held specially sacred under each form of faith. So also when a warrior swears by drinking the milk of his own mother, or when the hero swears by placing his hand on the body of the person adjured, or by drawing a line on the ground with his nose, we are taken back to survivals of forgotten animistic belief. That there should be in the Legends occasionally a mixture of Hindu and Musalman ideas in the forms of oaths will not surprise my readers; and of this a fine example is the phrase : "The Ganges is between us and above us is the Quran," said by so strict a Musalman as one must presume a Qazi to be.

The object of the ceremonies and forms used in taking oaths is of course to render them binding; but it must long ago have been equally important at times to avoid the consequences of rash and indeed deliberate oaths; and the inventive ingenuity of the folk has been turned on to this side of the question with considerable success. E.g., it is a happy and simple, not to say a convenient, expedient to interpose the presence of a pigeon's egg as an effectual stopper to the binding effect of an oath on the Quran.

In the matter of vows and oaths the Legends give a great number of instances in which a certain form of oath or vow, used for many purposes, but generally for emphasis, has become common to both Hindus and Musalmans. It has arisen out of the Muhammadan custom or law of divorce, tin taldg as it is called in India. The custom is due to a passage in the Quran which lays down that if a man with the proper ceremony pronounces dismissal (taldq) three times to his wife, he cannot marry her again until she shall have been married to another man and divorced by him. Now this solemn performance of tin taldg, or three 


\section{IO The Folklore in the Legends of the Panjab.}

dismissals, has evidently presented itself to the Oriental mind as a very serious vow or oath, it matters little which; and we constantly find in consequence that not only the notion, but even the very terminology of this form of divorce has come to be synonymous with that of taking a binding oath or vow. There is among the Indian peasantry a regular custom nowadlays of emphasising both oaths and vows by taking them three times.

Besides the miracle and magic working powers, there are two others of importance, which may be said to be inherent in saints, those of prophecy and metamorphosis. In the Legends the saintly power of prophecy is usually introduced for the very useful story-telling purpose of indicating the unborn hero's career as about to be developed, and the power of metamorphosis for the purely folklore object of helping on the progress of the stories connected with the saints, or those in whom they are interested, or with whom they have been concerned.

Metamorphosis is a belief that has struck its roots deeply into the minds of the Indian folk; and hence we find it constantly occurring in the hagiological legends. The saints can assume any form that is necessary to the tale or likely to attract the attention of the audience, can change the forms of others, and delegate unlimited power of metamorphosis to their followers. The idea so obviously lends itself to fancy that the variations of it assume forms most startling to the everyday man. In the Legends there are many astonishing extensions of the notion, of which turning the Deity himself into a dog in a legend about Namdev, for the purpose of pointing a moral, is perhaps the best example. $\Lambda$ dog ran off with the saint's (jogi's) food, and, instead of beating him, the saint addressed him in language applicable properly to the Deity. For his reward the dog turned into the Deity, and thus the saint had the inestimable privilege of beholding the Deity in person.

In the application of the theory of metamorphosis to folk- 


\section{The Folklore in the Legends of the Panjab. $41 \mathrm{I}$}

tales, we also find another indication of the fundamental identity of the hero, the saint or supernatural mortal, and the god or supernatural immortal in the popular mind. The power is possessed by all alike, and by none to a specially great or striking degree peculiar to himself. It is equally possessed by inanimate objects. In the Legends there are indications that the forms it especially assumes are due to two causes: the perceptible effect that disguises have in altering the apparent nature of human beings, and the changes of skin and plumage that snakes and birds undergo; and the old-world belief in metempsychosis or transmigration of souls, by which the Indian and Far Eastern peoples have for so very long been thoroughly permeated.

Disguises for the sake of enabling the hero or heroine to carry out their respective objects are very numerous; but the essential poverty of peasant ideas, despite their apparent diversity, comes out in the fact, that the disguises are apt to run in grooves and become stereotyped. As a rule they are such as might be expected; but there is a notable instance of metamorphosis by a humanised serpent merely for the sake of disguise; and it may also be said that many of the objects for which disguise is used are identical with those for which metamorphosis is made to take place. Disguise may be said to be, indeed, merely metamorphosis with the marvellous left out. Changes of skin or clothing, or of things pertinent to human and animal heroes, are so directly connected with metamorphosis, and so constantly in Indian folktales, as to give rise to a temporary form of it, of which many instances will almost without effort occur to those well acquainted with the tales.

The allusions to the doctrine of metempsychosis in the Legends are of course ubiquitous, but without much variation; and they habitually refer to the variety of lives the heroes and heroines have already passed through in diverse forms. In fact, the sole difference between the folk notions of metamorphosis and metempsychosis lies in the fact of the 


\section{I 2 The Folklore in the Legends of the Panjab.}

former consisting of change of form during life, and in the latter after death. The two ideas are very closely connected, so much so that the special changes represented by metamorphosis are based on the variety of bodies, that one and the same unfettered soul is assumed to be capable of vivifying.

In passing, it may be here mentioned that metempsychosis is in the Legends most ingeniously dragged in to defend the doctrine of sati, which is indefensible, except politically, even from the native scriptural point of view. A victim of the custom is made to say: "For many ages will I obtain the same husband," i.e. in reward for becoming sati. In the Legends, too, heroines are significantly made to commit sati, not only on husbands' but also on sons' deaths.

It will have been seen from what has been above said that saints scarcely differ from folktale heroes of the conventional sort. They are beautiful in appearance; they have all sorts of secular occupations, even finding a livelihood as private soldiers and horse-dealers; they have obvious foibles of their own; they claim kingly rank on assuming saintship, make royal alliances, and keep up a royal state; they are known by special and peculiar signs, they perform conventional heroic acts in an heroic supernatural manner. Indeed, just as the saint is hardly to be distinguished from the demon, so is he hardly to be distinguished from the ordinary folk-hero. Indian demonolatry is ancestral or tribal hero-worship, and Indian hagiolatry is very litle else. The saints and their demoniacal, heroic, or godlike counterparts are, however, essentially supernaturally endowed beings of the narrator's own nationality or party; but there are in Indian folk-idea other supernaturally endowed beings, demoniacal in their nature and usually styled râkhas and translated "ogres," who belong as essentially to the enemy's party. In the demon world the bhita, especially in South India, may be said to be always of the narrator's own class or side, and the rakkhas to belong to the outside world; while the demon proper 


\section{The Folklore in the Legends of the Panjab. 413}

(deo) may be looked on as being on the borderland between the two, and as belonging as much to the one side as he does to the other, occasionally exhibiting the characteristics of the ogres as clearly as he does those of the saints, heroes, godlings, and what not.

In translating râkhas in its varying forms, I have adhered to the usual term ogre, as being its best European representative, both expressions indicating, as $I$ take them, the foreigner who has at one time inspired fear, and has, therefore, been credited in the popular imagination with certain terrifying supernatural powers, attributes, and habits. The essentials of Indian ogre-stories seem to be constant. The ogre feeds on mankind, an idea extended to feeding voraciously on the larger animals also. He worries the hero's people and friends, and he is finally conquered by the hero, in fair fight, by miraculous intervention, or by conventional exorcism. He is, of course, a giant, and supernaturally endowed, performing much the same miraculous feats as his heroic or saintly opponents. In many respects he may be fairly described as the hero on the other side, his attributes as the result of the fear he inspires, and the struggles with him as vague memories of long past tribal fights with remarkable foreigners.

In one notable passage, showing how ideas extend and run into each other, in a fragment of a modern version of the far renowned (in India, that is) Sindhi story of Sassi and Punnun, we find that ogres and man-destroying monsters of all kinds are closely classed together. The fragment is based on the very celebrated (in India) poem by Hasham Shah, and for the present purpose I will quote the original:

Adambkor jandwar jal da, rakas rap sarden: Afjarmachh, kackhu, jah-hiri, udg, sansir balien; Tandue, hahar, zambaran-wdile, liwan sor tadien.

Man-eating monsters of the deep, like unto ogres ; Alligators, turtles, mermaids, serpents, and world-horrors , Crocodiles, dragons, porpolses, were bellowing aloud. 


\section{The Folklore in the Legendis of the Panjab.}

Of the same nature in Indian story as the ogre is the $n d g$ or serpent, this important fact being strongly emphasised in the Legends, in which the serpents and their doings occupy a prominent place. They here, though not in ordinary belief, appear just as ordinary heroes, and are distinctly human in their personalities and all their ways, as often appearing in human as in other forms. They are servants to the hero's patron saint ; they live in human dwellings and show hospitality to human heroes; they are subject to human diseases; they give their daughters to, and marry the daughters of, human neighbours. They are divided into families, and like ogres they live on human flesh. Like the rest of the heroic or supernatural world, they have a wide power of metamorphosis: into and out of human or serpent form, into many animal forms and into a variety of things, such as fruit, a fine needle, a golden staff, a blade of grass. In the same way they have an almost unlimited power of working miracles, chiefly malevolent; destroying life in various ways, setting on fire and scorching with their breath, or bile, or by the flash of their eyes, and drinking up the life of another. But they have an equally pronounced power of restoration to life, ordinarily by the recognised folk-tale methods. And, lastly, apart from being frequently "winged," they have the usual heroic powers of rapid and miraculous movement.

Now, the notions exhibited in these modern legends on the Naga serpents go back a long way in Indian story; and I think it a fair inference to draw from them and their prototypes, that Indian serpent-legends are but a memory surviving in an ignorant and superstitious peasantry of an old life-struggle between the Aryan population and the perhaps aboriginal Naga peoples, whose totem, so to speak, or even mercly national fighting emblem or standard, has, it may be, become confused with the race.

From the ogre and the ndga one passes almost imperceptibly to the humanised animal that appears so constantly 
in Indian legends, and plays so conspicuous a part in the stories loved of the people. The humanity, so to speak, of the animal, i.e. the non-human, world of beings is most strongly marked in all Indian folklore. Indeed, human and non-human beings seen hardly to be distinguished in the minds of the peasantry. In the Legends we find in one clear instance a distinct ascription to the latter of an immortality of precisely the same nature as that universally attributed to mankind. "He took the bullocks at once to the river. They began to drink in the river, where a serpent was on the bank. Bitten, they fell to the ground and their life went to the next world." Here the actual expression used is: "bhawar Baikunth lok ko dhaya, the breath went off to the world of Paradise"; just such an expression as would be properly applicable to a human being. In another strong instance a parrot describes itself as "a good Hindu," requiring a purification ceremony after touching a dead body.

Human characteristics may be expected in tales of the customary Oriental animal-pets and companions of mankind, such as the horse, the bullock, the camel among quadrupeds, the parrot, the maina, the falcon among birds. And there are many instances in the Legends in which the doings, sayings, and feelings of all of these are hardly to be differentiated from those of the human actors. It may be here noted that the absence of any allusions to a sense of companionship between man and the dog marks a point of wide divergence between ordinary Oriental and European feeling.

There is, in fact, scarcely any characteristic or capacity of the human that is not equally attributed to the nonhuman world. All sorts of animals act as messeogers. Serpents, cattle, and birds are of course described as being affected strongly by music. Serpents and deer, extended in one case to "all the beasts and birds of the forest," are attracted by human beauty in a human manner. $A$ 


\section{The Folklore in the Legends of the Panjab.}

swan falls in love with the heroine in the human sense: deer can dream human dreams: a swan is made to address the Creator (Kartâ) by way of prayer, and a doe to distinctly pray to God ( $k \hat{i} t \hat{t}$ Rabb agge faryâd).

The grateful animal is a stock expedient in folktales, and we are treated to instances of all kinds in the Legends, some of which may be called unexpected. Thus, in this category appear cats, crickets, hedgehogs, serpents, swans, crows, cranes. The opposite quality of ingratitude is also ascribed to a deer and a parrot. And in the quaint legend of Dhanna, the Bhagat, a god consisting of an ordinary commercial stone weight, is made to play the part of the grateful animal, using the term in the sense of a non-human being. But the legend here has more than probably an origin in a consciously allegorical story.

Just as animals can be grateful and ungrateful, so can they be revengeful; and of revenge on human lines there is a fine instance in the tale of the humanised Hira the Deer in the Rasalu Cycle, who throughout acts the part of the ordinary folk-hero. The tale goes even to the extreme length of attributing caste feelings to the herd he belonged to ; for "they cast him out of the herd because he had no ears or tail" (they had been cut off). But perhaps the strongest possible instance of humanisation occurs in the same Cycle, where a lizard as the hero and a female serpent as the heroine play a variant of the story of Potiphar's Wife.

The direct and almost universal use in story of the animal with human attributes is to help on or interfere with the action of the hero in a simple or in an extraordinary manner, as when cranes, crows, parrots, and falcons act as messengers, a falcon takes his turn at keeping watch, and a flock of birds stop the progress of a ship by merely sitting on the shore. In order to do these things they must be able to talk, and do so as naturally and freely as do the men and women themselves. But the use of 
unnatural powers of speech is carried very much further, and they are habitually attributed to everything that is introduced to forward the story or the interests of the actors therein. Indeed, in the legend of Niwal Dai we are expressly told: "It was the virtuous time of the golden age ; all things could speak their mind." An expression used again in the legend of Raja Dhol in almost identical but more limited terms : "It was the golden age of virtue, and the cranes spake." An astonishing variety of objects is thus supposed to be gifted with speech. Any kind of plant for instance: trees, mangoes, plums, pipals, plantains, grass. All sorts of articles in domestic use : a bed's legs, a lamp, a pitcher, a necklace, a conch, a couch, a needle, a pestle and mortar, a garland. Even such a general object in nature as a lake. In one instance a sandal-tree relates its very human adventures merely by way of incident. Anthropomorphism could hardly go further.

It is, however, carried p......... in an instance that occurs in the fruitful Rasalu Cycle in two versions. A corpse, restored to life through the prayers of the hero, helps him out of gratitude in such a matter as a gambling match, in one of the instances. In the other, the corpse appears as a number of severed heads, whom the hero adjures not to weep and to help him with their prayers. After all this the story of the well-known parrot of Raja RasAlu, that "was wise, knowing the Four Vedas," could answer riddles and give wholesome human advise, falls somewhat flat. And the common folk-notion of a foetus speaking from the womb becomes, as it were, natural. It is the stock miracle related of Guru Gugga, but attributed also to a good many other personages remarkable in subsequent separate life.

It will have been noticed that the notion of the humanised animal slides almost imperceptibly into that of the bumanised thing. When once the habit of anthropomorphosis comes into play it appears to matter little whether it be VOL. $x$. 


\section{The Folklore in the Legends of the Panjab.}

applied to an animate or an inanimate object, and especially is this to be observed in the case of things held to have been subjected to the action of miracles or magic, i.e. to things charmed or enchanted by visible or invisible agency, the main use for which in the Legends, it may be observed, is to assist the hero or the progress of the tale about him: e.g., enchanted dice made out of such uncanny objects as dead men's bones, which always win.

The well-known enchanted or protecting circle or line, within which no harm can come, taking us very far back in Indian belief, is but hinted at in the Legends, though its descendants the ascetic's necklace and rosary commonly occur. But the more practical means of defence, such as magical or enchanted arrows, play a considerable part. Thus, there are several instances of the use of fiery arrows, varied in one quaint instance as the fiery quoit, a survival of the classical magical quoit of Krishna, and in a still quainter one as an arrow of cold. This last variant is clearly due to an expansion of the general idea of the fiery arrow, for it is introduced for the purpose of combating fire: "Then again Arjun shot an arrow of cold and all the enenies' bodies trembled. Then were the sun's rays obscured and day turned into night. Frost and cold began to fight with lire."

Magic numbers of course exist in India, chiefly in the forms of multiples or parts or combinations of seven and twelve, but I do not think that the peasant mind sufficiently grasps such abstract notions as numbers to lay much stress on any enchanted properties that they may be supposed to possess. I have carefully collected every number that occurs in the Legends, and the general conclusion is this: that as to the larger numerals no clear conception is entertained at all. They all mean a very large quantity to the peasant story-teller, and for that purpose one large figure is as good as another. As to the smaller numerals, there is but a dim idea that there is somelhing holy or sacred or supernatural 


\section{The Folklore in the Legends of the Panjab. 419}

about some of them, they are not sure which, and they never remember them accurately.

The most wide-spread and familiar, but perhaps not the best recognised, article subjected to supernatural agency is holy water, as common in India under Islam and Hinduism as it is in Europe under Christianity. In the Legends its uses are to invoke "the blessing of the great saints" and to effect miraculous cures-uses that will recall ideas current outside of heathenism. Much of the virtue of holy water is transferred in the popular mind to blood, especially human blood, which is the main folk-agency for miraculous restoration to life and health, and a common one for the performance of a host of other marvellous feats. In the Legend's these virtues are to a certain degree yet further extended to milk, and it is of interest to record that in them ambrosia or amrita not only turns up as the beverage of the gods, but also when pure as holy water, in a most remarkable passage in a Hindu story, where it is regarded as the blood of the Almighty :

\section{Kirpa hut hai Sakat kt: hut Quarat ki khiydl: \\ Apnt unglt chirke amrit lid nikdl.}

The Almighty had mercy : the All-powerful considered them:

Cutting his finger he drew forth the water of lifo.

In India, however, all water may be called in a sense holy. There water of itself purifies, an idea that still leads to an incalculable amount of disease and sickness. The rivers and pools are all more or less sacred, though some of course are pre-eminently so, and ceremonial bathing is a source of infinite gains to the priests and holy personages.

The enchanted miraculous vehicle is a very old and widelyspread folk-notion, and so we find all sorts of heroes, saintly and demoniacal, flying through the air, leaping the ocean, accomplishing a journey of months in a few paces, and proceeding about their business at any required rate of speed on a variety of unlikely articles, of which abnormally winged creatures, bulls, lions, horses, camels, and the like are but 


\section{The Folklore in the Legends of the Panjab.}

variants. So closely do we find the two ideas conected, that $I$ have sometimes thought that the whole notion of the miraculous vehicle and its concomitants is nothing but an expansion of the heroic leap, which in its turn is a mere popular exaggeration of some actual feat. In the Legends the idea of personally flying through the air is extended to making a saint's shoe to fly through the air in order to punish the saint's opponent by beating him. This causing of things to move miraculously is to be further seen in the common miracle of a saint moving his tomb from one place to another, leading to the quaint practice, observed by myself in Hindu India, Buddhist Burma, and even Japan, of chaining an image to prevent its returning to the place whence it miraculously migrated.

The value of invocation or calling together the tribe and its defenders by a loud cry or sound must necessarily have been a very early human observation; and its importance and weird suddenness when used has all the world over led to some fanciful and pretty notions as to magical music and enchanted instruments, dependent chiefly on the observed or fancied influence of musical sound on the animal world. In these Legends there are distinct evidences of the history of the idea, and the chief use to which the magic flute, or its variant the magic conch, is there put is, where it is used by the secular hero, to call together the tribe and its friends, or where it is used by a saint or religious leader, to collect his following, celestial or terrestrial. Its secondary uses are to play upon the emotions of friendly animals, and to call to the aid of the hero the attention of the gods and the invisible inhabitants of the celestial worlds, who, where the hero is a saint, usually seem to occupy the place of his subordinates and assistants. The sound of the flute or conch seems also to have become mixed up in the popular mind with the "voice of prayer," for it can "reach to the Court of God," and so secure the divine intervention in human affairs. 


\section{The Folklore in the Legends of the Panjab. 421}

The power of enchanted human hair to assist human beings-perhaps as a spirit-haunt, to use Sir James Campbell's phrase- is another world-wide and very old notion, and again in the Legends we seem to get at an explanation of it, for it and its counterpart, the insect's feeler, is of no avail until burnt, an idea arising probably from the palpable effect burnt hair has on those who become insensible from a blow or disease. The concrete idea, however, in burning hair appears to be to drive the spirits out of it by the process, and so compel them to your service; for the actual use of burnt hair is to call up invisible assistance. But when once the hair has started on its career as a power to interfere in the affairs of man, it is made to do a variety of things for him; for it can, among other things, cut down trees, burn up forests and enemies, and lead the heroine into her enemies' clutches. The outcome of the belief in the virtue inherent in hair has been a variety of Oriental beliefs and customs deriving directly from it:-e.g., the sacredness of the Musalman's beard and of the entire hair on the body of a Sikh.

To pass from a part to the whole, the great power possessed by enchanted human or animal bodies is invisibility. But I do not think its constant use in folktales and in these Legends is altogether due to a love of the miraculous. The notion gives such obvious opportunities for investing the heroes and actors with a deeper interest than they could otherwise be made to possess, and especially saints with additional supernatural powers for overawing those who listen to tales about them, that neither story-tellers nor bards have anywhere refrained from taking advantage of it. The practical use to which the power of invisibility is put in the Legends is to help on the development of the tales, or to assist the hero or the heroine in their desires, or to glorify a saint or holy personage.

Curiously enough the procedure of enchantment is not anywhere directly given in the Legends, though of course it 


\section{The Folklore in the Legends of the Panjab.}

orcurs often enough in the folklore of the country. All the enchanted articles that occur are supposed to have already undergone the processes necessary to render them supernatural. Probably the audience is assumed to know what those processes were, and such charms as occur are all of the prophylactic nature already described.

Between the supernatural and unmistakable human being there has existed everywhere and at all times an intermediary, a being who, while obviously and distinctly human, has assumed or acquired certain unusual and therefore in the popular mind uncanny powers. His ordinary form is that of the priest, but the forerunner, and in early society the contemporary, of the priest is the being who is possessed, i.e. subjected to enchantment, magical, supernatural, or miraculous. Spirit-possession is not a desirable accident of life, especially as sudden, severe, or striking disease or illness is confounded with it; and hence the existence of the possessed has led to that of the exorcist or professional curer of the misfortune. The idea of possession and its antidote does not scem to have taken a strong hold of the Panjabi, and consequently not much of either appears in the Panjab Legends. Indeed, it is directly mentioned only in one place; but in many respects a remarkably similar series of legends from Kanara, which I have somewhat recently edited under the title of the Devil-Worship of the Tuluvas, mainly turns on it, as indeed does the whole complicated system of modern Tibetan Buddhism, exhibiting once more that common phenomenon in nature, the rudimentary existence only in one series of connected creatures of a part that is fully developed in another.

So far, we have been dealing with the heroes and their male counterparts, but on turning to the heroines it will be found that, so far as Indian ideas on the parts that the sexes are capable of playing in the affairs of life admit, the stories of the female actors follow striclly on the lines of 


\section{The Folklore in the Legends of the Panjab. 423}

those of the male. The main cause of the differences observable lies in the low estimation in which women generally are held by the populace-a fact typified in the Legends by the belief that it is not only foolish, but socially indiscreet, to praise a woman, especially one's wife, by the ceremonial observances demanded of the women towards their male relatives, all intended to emphasise their position of subjection, and by the universal custom of the seclusion of women.

The typical heroine is emphatically a child of predestination, "tabued," as it were, from birth to the hero. Her characteristics are impossible strength or skill to save the hero in trouble, as when she cuts a tigress in two; or, on the other hand, impossible delicacy, as when she is weighed against flowers; or she is endowed with impossible attractiveness, dropping nowers when she laughs and pearls when she weeps. Her beauty is, of course, all-conquering, the animal world, the heavenly bodies, and the God of the Waters (Khwaja Khizar) succumbing to it, and like the hero, she is known by "signs"-e.g., by the bubbling of the water in a well when she looks into it.

Of beneficent heroines we do not hear much in the Legends. Perhaps it is hardly to be expected that amongst the Panjabi peasantry a woman could be held to be of much assistance in life. The fairies, when they do appear, are accordingly merely messengers between this and other worlds, or they represent outside, unorthodox brides or mistresses of Rajas or heroes. But of maleficent heroines we hear a good deal, and of the victims, male and female, of their active ill-will. Calumny, born of jealousy, is the favoured method of showing it. Jealousy of a co-wife, natural enough where polygamy is practised, and of a co-wife's children, gives so commonly the spring to vindicative action, that the story of the calumniated wife may be looked upon as a special variety of Indian folktale, though the enmity is sometimes represented as being ex- 


\section{The Folklore in the Legends of the Panjab.}

tended to the husband, the husband's sister, and the nurse or duenna.

To the category of malevolent heroines belong the stepmothers, who play a prominent and peculiar part in Indian folktales, due to the polygamy practised by the rulers, the rich and the great. They are nearly always the malignant co-wives with the hero's mother, interfering in his life and story in two main ways-i.e. they either get him into trouble by acting after the manner of Potiphar's Wife, or they seek to ruin him out of jealousy of his mother. From the latter cause the heroine is also frequently made to suffer at the hands of one or more of her stepmothers. The methods of the stepmother of arriving at her ends are, however, generally human, and the women held to be endowed with malevolent supernatural powers are the wise-women, witches, ogresses, and ndgnis or serpentwomen.

So far as the legendary lore is concerned, we may treat witch and wise-woman as synonymous terms for the same class of wicked woman. Both invariably play the same part in a tale and have the same characteristics. They are the marplots, the malignant fiends of the story; and their natural occupation is to place the heroine in the power of her enemies-of which, assistance to the hero to get at the heroine in irregular manner is but a variant. They have disgusting and terrible attributes. They are cannibals, and take out the liver and eat it. They have second sight, and are suspected of knowing things that are hidden. But they are not necessarily ugly or uncomely: often, indeed, they are the reverse. In order to attain their ends they are endowed with the power of metamorphosis and miracleworking- "setting water on fire" being in one instance claimed in the Legends as a difficult feat, which no doubt it is.

The ogress is in every essential merely a female counterpart of the ogre, with the same attributes, the same super- 


\section{The Folklore in the Legends of the Panjab. 425}

natural powers, the same enmity to the hero's race, even as the $n \hat{a} g n \hat{\imath}$ or serpent-woman is just a woman of her kind, with all the $n d g^{\prime} s$ attributes, humanity, habits, and powers. In their struggles with the human or heroic races their methods, though necessarily differing from those of the males of their class, are in each case of the same nature. Thus, instead of directly fighting mankind or the heroic opponents, they seek to destroy them by winning them over by female blandishments, and so getting them into the power of themselves and their party.

Besides what may be called the heroine proper of a legend or folktale, the child miraculously born and predestined to great deeds, the legitimate pride and glory of the tribe or race, there is the foundling, that kind of child which has come irregularly or illegitimately into the tribal or family circle, to play an important part therein. The career of the foundling may be expected to attract the imagination of a peasantry. Such an unexpected and unlooked-for addition to the family or tribe is sure to be interesting and to give rise to hereditary tales. But apart from the interest attaching to the conditions under which foundlings are introduced, the exigencies of native life serve to create and maintain foundling-stories. So many subcastes and tribes and so many families of the upper ranks have from the native point of view a doubtful origin, so many of the richer people, who can pay for bards and their flatteries, have a blot on their escutcheons-a bar sinister, as one may call it-that tales of foundling girls are bound to flourish in order to connect families, castes, tribes, and prominent personages of the day with those of bygone times, whose position and claims are held to be beyond all doubt. Ancestor-making and genealogy-inventing are arts well understood in India, especially by the bardic class; and the story of the foundling mother of the eponymous hero is the most cherished resort for the purpose. In the Panjab, that land of great rivers, the river-borne foundling 


\section{The Folklore in the Legends of the Panjab.}

is the favourite variety. The girl infant is discovered floating by various methods down a river, is adopted by the finder, is married to the eponymous hero or his father. is subsequently traced to an aristocratic family, and the desired high-class connection is established. A dive into any of the accepted accounts of the more important families, or into the legendary history of the sub-tribes and sub-castes - even into that of the tribes and castes themselvesanywhere in India will produce many such stories in many quaint forms. They abound in the folktales and appear in the Legends of course.

Pretly and popular varieties of the foundling-tale are to be found in the many variants of the egg-hero story, where the little stranger, male or female, is fabled to have sprung miraculously from an egg, from fruit, from a box, a flower, or other small and fanciful article. And to the same category must, I think, be referred the universally popular sleeping-beauty. A careful survey of her life-history, the manner of her discovery, her doings and characteristics, point her out as the representative of the bride from the other side-raped it may be, or stolen, or abducted, or taken in fight as a sort of spolio opima, or perhaps simply found. Whatever she may be, princess in disguise, ogress born, or captive in a foreign land, she is emphatically not of the hero's race or party, and their union is always irregulari.e. nol according to established tribal custom.

In one essential point, arising out of the view taken by the peasantry of women and girls, the folk-heroine differs entirely from the hero. As the actual property of some male, either tabued to him or as part of his personal effects, the heroine has to be chaste. Of male chastity we do not hear much, except as virtue-i.e. manly capacity, which is quite a different idea from that atlached to sexual chastity. Of virtue in the above sense a great deal is heard, and it is most jealously guarded. The terms usually rendered "pure" and "chaste," and so on, however, never imply 


\section{The Folklore in the Legends of the Panjab.}

male sexual purity, and Raja Rasalu, a hero essentially of gallantries of every kind, is repeatedly called "jati sati, pure and chaste," in the sense of being endowed with unimpaired capacity. He was in that sense fully virtuous. The possession of such virtue is made a condition of worldly power, and when possessed in an inordinate degree calls down the wrath of the supernatural powers as a positive danger to them. It is also a vital point to keep out of touch with women at periods of stress and trial in order to maintain it, their approach and proximity impairing it. The origin of all this is obvious, the male is not subjected to tabu or appropriation, and the female is.

Perhaps the neatest indication of the point that of old chastity was the virtue of women and virile capacity the virtue of men, is shown in the manner in which the zone, both as a word and as an article of costume, was used. There was always the female girdle or zone, the emblem of chastity, and the male zone or sign of virility and fighting capacity. In the Himalayas the silver zone is still the sign par excellence of a warrior. Says a legend: "The Lord Raja is coming himself to this war. He has called every wearer of a silver zone to Junga."

Now, the very line of reasoning which renders male chastity of no account, makes female chastity the main virtue-i.e. capacity of the sex. In such a society as is reflected in Indian legendary lore, it was as essential for a woman to be chaste, as it was for man to be of his hands capable. The maintenance of the tribe and its social structure rested on these features of the two classes of human beings composing it. We Europeans have the remains of this feeling in all our languages when we talk of a woman and her virtue. Female clastity, then, being of such very great importance to the men, and also so very difficult to secure without the co-operation of the women themselves, the men were always calling in the supernatural powers to their aid in maintaining it, out of their 


\section{The Folklore in the Legends of the Panjab.}

natural and well-founded suspicion that such co-operation did not exist. Of this there is universal folktale evidence, and it gives occasion to resort to ordeals, both practical and supernatural, more often than anything else-except perhaps the cruel "wisdom" of the witch-finder-by fire, by dice, by water, by impossible tasks and conditions. However, it being on occasion most important to prove the virtue in a hero, ordeals of the same kind are resorted to in tales for that purpose also, and not only has the hero to prove that he is a man of parts, but the saint, too, has to show the peculiar virtue in him by giving a "sign," usually in the form of a miracle. Indeed, many miracles are merely forms of ordeals.

The extravagant extension of any idea for the purposes of story-telling, may be looked for in all the literary productions of the folk, and in the Legends, by way of emphasising the grave importance of female chastity, the famous heroinc, Hir, before what we, but not the natives, would call her fall, is in one place said to feel polluted, simply because the hero occupied her bed in her absence.

The value to the early intelligence of ordeals for the discovery of virtue in mankind has led to their wide employment in folktales, for the intelligible and important purpose of proving the long-lost hero or heroine-for testing claimants, in fact. Tests, natural and supernatural, for their identification are ubiquitous in all folk-stories, and equally so in the Legends, leading in many instances almost imperceptibly into the region of prophecy and its fulfilment. Almost the whole stock of folk-ideas is pressed into the service of this most prominent necessity of the progress of a story. Heroes and heroines are identified by marks, personal characteristics, and properties, surviving still as "the signs of royalty," both possible and impossible, and by definite ordeals, such as the answering of riddles and the performance of impossible tasks; and, further, by resort to such purely mythological ideas as a correct 


\section{The Folklore in the Legends of the Panjab. 429}

recollection of details and surroundings in "a former life." On the other hand, there is in one instance a reference to that widespread, practical form of identification, which is embodied in the custom of placing a stamp or mark on the body or clothes, as a voucher of a visit to a shrine or of a pilgrimage completed, where the hero's camel carries away betel-leaves and water to show that he had really been to the heroine's abode, and so knew the way thither.

The favourite folktale form of ordeal is the impossible task, and naturally so, as the individual fancy can here range at will; while the poverty of peasant imagination is also shown by the constant resort of the story-tellers to well-known stock tasks. In one torm, however, the impossible task is of exceptional interest, for when it is imposed as a condition of marriage with the heroine, the Legend's show that it is the poor remnant of the once important political mancuvre of the swayamvara, or public choice of a husband by girls of princely rank.

There are two common variants of the impossible task frequently occurring in the Legends-riddles and ceremonial gambling. Conventional riddles preserved at the present day in garbled traditional verse, and usually perfectly unintelligible, are used for all the purposes of their prototype - for identifying the hero; as necessary preliminaries to marriage, and even to an illicit intrigue; as a variant of the swayamvara; as a kind of initiation into saintship; in fact, wherever an ordeal is for any reason desired. But the more legitimate use of riddles as a symbolical, or secret, or private form of speech is merely hinted at in the Legends, as where a birth is announced in the form of a riddle, and where the female attendants of a princess make communications in the same form.

Gambling is looked on by the Indian populace as the usual and proper occupation of the great and rich; and so a good deal is heard of it in the Legends. But the ceremonial gambling occurring in them bears evidence of its 


\section{The Folklore in the Legends of the Panjab.}

origin; for, as a test before marriage, it is clearly an ordeal in the form of a variant of the impossible task. In this sense it is regarded and repeatedly spoken of as "a virtuc of the rulers." Of course, in folktales and legendary lore, the notion is subjected to great exaggeration, and we are favoured with most extraordinary stories of reckless gambling-for property, possessions, and even life itselfand in the Legrends, with what is of far more importance, detailed descriptions in all its technicalities of the great and ancient royal game of chaupur or pachisi.

Passing thus without effort almost from the actors to the course of the story, we find that perhaps the commonest way of commencing it is to set the hero seeking his fortunes, either by way of a start to the story, or to get a living, or as the result of troubles at home, or in response to a prophecy or fortune-telling. This opens a wide door to preliminary incident, even to a relation of invaluable details ats to the prescribed modes of procuring oracles and forecasts of fate and fortune, which will be found on examination to be substantially the same all over India, north and south. Such oracles as occur in Indian tales are as vague in form and uncertain in meaning as elsewhere, leaving the inquirer to make what he can of them. A fine specimen, drawn from the working of the Persian water-wheel so universally used in the rural Panjab, and couched in good rustic verse, occurs in the Legend of Mirza and Sâhiban, though the hero scems to comprchend it without effort or hesitation :

The axle binds the shaft and the spokes bind the axle; The axle-tree lies on the ground fastened by strong chains; Wheel works with whecl as a king with his courtiers; The whole machine creaks as a beggar among husbandmen; The pitchers clink (ns they come up) full of pure water.

It could hardly be expected that the regular and irregular priesthood of India would allow so fruitful a source of class and personal profit as is offered by such a matter as fortunetelling to pass them by ; and so we are distinctly told that 


\section{The Folklore in the Legends of the Panjab. 43I}

the casting of horoscopes, or the grant of peeps into the future, is the peculiar province of the Brahmans.

The whole vast fabric of fortune-telling, prophecy, soothsaying, oracle-making, built up by the various kinds of Indian priesthood, is throughout Indian folklore and in the Legends to be seen to clearly rest on the universal and ineradicable belief in fate. Allusions to it are innumerable, and every act or chance of human life is referred to it as a matter of course-as an accepted incontrovertible proposition. The terms for fate and life are even found to be mutually convertible, though instances do occur in which, especially among Muhammadans, fate is distinguished from the consequences of evil deeds, being perhaps an echo there of Christian or Jewish or even Buddhist teaching. Of such a sentiment the following is an example: "If a bullet strike thy forehead, know it is the reward of thy (evil) deeds, know it not for thy fate." But such ideas as this are, however, extremely rare in story, and habitually every event is attributed to the action of fate.

Perhaps the best way of obtaining a comprehension of the depth and width of the sentiment of fatality among the Indian populace-a notion of the extent to which it permeates their ideas as to the causes of the events of everyday life-is by an examination of the ipsissma verba of the bards and popular singers, for which the Legends afford very many opportunities. It will then be seen that the popular philosopy really amounts to this-every occurrence is fated, the action of fate is visible in every event, is in. evitable, is pre-ordained, "written," or decreed. The very terms in which the actors in the Legends apostrophise Fate shows this strongly. Cries an unfortunate more than once: "What, Fate, hast thou written in my fate?" Cry others again and again: "O Fate, what hast thou done?" "O Fate, what is this that thou hast resolved on ?"

Widely differing occurrences are repeatedly attributed to the direct action of fate. Typical expressions are the 


\section{The Folklore in the Legends of the Panjab.}

following: "The matter was in the hands of Fate, and she (the wife) saved the Raja." "Thou wast not in fault, my Lord, it was in my fate." "What is to be must be borne; why make plans (to avoid it)?" "Fortunate is our fate that the Court remembers us." "Thy fate is evil." Here are expressions that recur repeatedly: "I, too, am Fate's victim." "I die for her sake, my fate hath come." Says a king of his minister: "His fate and mine were one." Says an enemy, feeling that he had no chance otherwise: "If Puran's fate be awake (i.e. against him) I will come back and slay him." Cries a young girl: "All my studying is over, for Fate hath brought me love."

The difficulty of accounting for occurrences-the inscrutability, in fact, of fate-has of course forced itself on the peasant mind; and the feeling finds voice in their exclamations, of which "There is no fathoming fate" is perhaps the commonest. The most conspicuous quality, however, of fate is necessarily the inevitability of its action, and we accordingly find this fact expressed in many different and sometimes quaint terms, of which good examples are: "The rest is in my daughter's fate (over which) none have power." "Who can vary the lines of fate?" "This (a throw of dice) was in the power of fate, no power (of ours) avails." "Thy fate hath encompassed thee and there is no way to save thee." "Fate is not to be gainsaid, and God doeth as he listeth." Here is a strong way of putting the rustic view: "Fate hath come on thee: when fate slew such prophets, shalt thou escape?" Perhaps the most usual ways of all of expressing the hopelessness of lighting against the inevitable are: "What fate has written who can blot out?" "There is no remedy against fate." And lastly a curious belief in the godlike powers of the founder of the Sikh Religion is to be seen in the expression: "What fate the Guru (Nanak) hath ordained cannot be avoided." But the pathetic cry of a mother over a murdered son seems to point to a latent hope in the villagers' hearts that perad- 


\section{The Folklore in the Legends of the Panjab. 433}

venture, for all its inevitability, the action of fate may possibly be avoidable: "Death met him in the street and fate stopt the way (for flight). When thy fate was written had I been by, I would have made a great cry to God and had it written favourably."

The usual way of stating the inevitable is by viewing it as written or decreed by fate. The common expression is : "It was written in my fate ; thou canst do nothing." And there also occurs twice in the Legends: "See, this was written in the lines of fate, this misery of mine." A religious fanatic in order to account for his mode of life, says : "Mendicancy was written in my fate:" and it is further said of a herdsman: "God wrote no labour (in his fate); he was to be happy with (tending) buffaloes." Of a parted husband and wife it is said: "This much connection was written; fate hath done this." Again, one of three brothers puts the Panjabi peasant belief very powerfully when he explains to a judge: "Chiefship was written in Chuchak's fate and lordship in Michru's. In'my (Kaidu's) fate was written saintship ; it was the writing of God."

The decree of fate occupies a prominent position in Indian idea, and typical ways of giving expression to it are such as these: "The decree that fate has written down against me have I suffered to the full." "O Queen, if posterity had been decreed in my fate, it would have been through you." "The decree of my fate (leprosy) hath been passed upon me." The commonest expressions of resignation are: "The decree of fate must be borne," and "Pain and grief are with all; it is the decree of fate." The notion has even passed into a frequently recurring proverb: "The decree of fate is strong and waits not for postponing." Cries one of a number of refugees from an unhappy political struggle: "It was fate's decree that drove us to the forest."

Fortune-telling in all its forms involves the intervention of a second party; but forecasts of fortune can also be sought within one's own personality, as it were, by the interpretaVOL. $x$. 


\section{The Folklore in the Legends of the Panjab.}

tion of dreams; and so dreams, their results and their meaning, play an important part in Indian folktales. They frequently occur in the Legends, where they are usually of the prophetic sort, a start being given to a story by the hero's dream of the heroine or vice versâ; an idea neatly turned to practical use in some stories of saints by making the sainily hero fix on a preceptor owing to a dream. The idea is further useful in tales about the recovery of recalcitrant followers, by making the saint terrify them through dreams. The actual method of utilising dreams in folktales is to make the hero or heroine follow them up in their subsequent waking hours, often to their great temporary tribulation. And of the familiar warning or prophetic dream of the western world, there is one quaint example, in which a doe is made to warn her husband, the buck, of his impending death at the hands of the huntsmen, by telling him a vividly related dream as to the details of it.

The interpretation of dreams is a form of augury or divination, i.e. it is a means of foretelling the future from occurrences to human beings which are beyond control, though the latter terms in themselves imply an attempt to forecast the future from natural occurrences beyond human control that take place only in the surroundings of mankind. In the Legends direct references to augury and divination are few, and then only stock ones relating chienly to marriage cercmonies; which last may in India be best described as one prolonged effort to sacerdotally control and foretell the future. But all over the world the commonest and most universal mode of arriving at an idea of the future from chance occurrences in the natural world around us lies in omens and their interpretation, and of these we are treated to a great number in the Legends, as might be expected. They are all, however, of the usual sort, except perhaps that it is unlucky in the Himalayas to give milk to a warrior on the war-path. With this exception we have dished up for us the well-worn superstitions relating to the meeting of 
lucky and unlucky personages, to lucky and unlucky things in nature, plants, trees, and so forth, to the flight and calls of birds, to sneezing, which, like hiccough, is a most mysterious proceeding of the animal body to the Indian mind, to accidental occurrences on mounting a horse and while walking, and so on.

Following on and arising out of the notion of fortunetelling, augury, divination, and omens are the actions necessary to ensure good fortune or luck; the lucky things to do, and the lucky times for doing them, such as swinging during the rainy season. And as everyone is of course interested in finding these out, we are everywhere favoured in Indian folklore with a goodly array of them, and amongst lucky acts may be mentioned as noticeable, that of mounting a horse with the left foot, a curious instance of giving a semi-religious sanction to an act that is otherwise right from a practical point of view. The sole use to which the "science" of astrology is put in the Legends, is to ascertain auspicious times and moments.

In folktales the main use of the idea of ill-luck is to fill up the tale by introducing a great number of incidents, describing all the misfortunes which fancy can call up as happening to the hero or heroine; but the thousand and one precautions taken in practical life against incurring misfortune are based upon far more serious considerations than this. To the Indian peasant mind misfortune is a sin, and indicates a sinful condition in the victim thercof, defining that very difficult and much ill-used term "sin" as an offence, witting or unwitting, against the tribal conventions. The good luck of the lucky obviously benefits their surroundings, and the bad luck of the unlucky as obviously brings harm. Therefore the unlucky are sinful and, what is of supreme practical importance to them, must be punished accordingly. The amount of misery and suffering arising out of this "correct argument from a false premiss" that is being and has for ages been incurred by the victims 


\section{The Folklore in the Legends of the Panjab.}

of perfectly involuntary and uncontrollable misfortunesuch as widows, for instance-is quite incalculable; and a little consideration will show why it is that the nostrums for the prevention of the dreaded $\sin$ of misfortune are interminable, both in variety and number.

Another most fruitful result of the primitive view of misfortune is the idea of ceremonial uncleanness, an "unfortunate" condition clearly the consequence of inadvertence even to the savage, which has led to unnumbered ceremonies and customs in practical life and to many incidents in tale and story. The ceremonially unclean condition, however much it may be natural or the result of mere chance, is perceived in a dim way to be somehow sinful or the result of sin; and hence the nostrums for avoiding the consequences thereof. But when the condition is intensified and exhibits itself in a lonthsome or continuous form, then to the popular mind its sinful origin is no longer doubtful. The story of that prominent, mysterious, obviously unclcan, loathsome, and much dreaded disease, leprosy, and of the native treatment of lepers in India, will bring out all these points; and the subject of lepers and leprosy, if taken up as a folklore study, would be found to cover nearly the whole range of belief and customs among the folk. In the Legends we see much of it. There, the separation, isolation, and treatment of lepers is due to their uncleanness, the origin of leprosy lies in sin and in the punishment of sin, and its cure is due to ceremonial cleansing.

In another direction, the doctrine, so to speak, of ill-luck has led to very serious practical consequences, a fact which is clearly brought out by an incident in the Legends. The birth of a daughter is announced to Raja Sarkap just as he had lost his great gambling match. "Kill her," said Raja Sarkap, "she has been born at an unlucky moment, and has brought me bad luck." But, as an instance where female infanticide, based on ill-luck, has been widely resorted 10, though from a different concrete origin, the whole of the 


\section{The Folklore in the Legends of the Panjab. 437}

celebrated historical legend of Mirza and Sâhibân is witness. Briefly, Sâhiban, a daughter of the Panjabi Siyals, eloped with Mirza, the Kharal, and was overtaken by her tribe and strangled. The subsequent feuds were so severe that it became unlucky to have daughters, and an extensive practice arose of strangling female infants in memory of Sahiban. This is an instance where folk-notions have actually affected history.

Now, the predatory portion of the priesthood has everywhere been most careful to keep alive and foster the folknotions of $\sin$, misfortune, and ill-luck, because out of them arises the most prolific source of all of a good livelihood for themselves. Sins must be expiated; sinful bodies must be purified; the priest is always ready to secure expiation and purification, and to guide the ceremonies enjoined in either case. Ceremonial bathing, as a result of the notion of the holiness and cleansing powers inherent in water, is the great panacea in India; and out of the holy bathingplaces perhaps more wealth has been transferred from the laity to the coffers of the priestly classes than from any* thing else that has been invented for the ghostly benefit of the people.

After providing the personages and setting the story going in a definite direction, the next thing necessary is to keep up the interest by the process known to adverse reviewers as padding, and to the sympathetic as valuable incidents. Those in the Legends are, as might be expected, of the stock description; scraps of well-known verses or tales, or references to stock notions about this world and its affairs. From the very nature of the circumstances under which they are introduced they offer the most undiluted folklore with which the narrators are imbued, and are thus often the most valuable part of a tale to the student. Thus, there are everywhere valuable references to the miraculous origin of that puzzle to the peasantry, a pearl or precious stone, or even a bright flower. Rubies are the products of 


\section{The Folklore in the Legends of the Panjab.}

the sea, or the special gift of the god of the rivers, or more fancifully still drops of blood from the murdered magical hero or heroine. Pearls are rain-drops during a particular asterisin; and both they and flowers are derived from the tears or laughter or speech, indifferently, of the hero or heroine, and so on.

A very large portion of the incidents observable in folktales are tricks, in the narration of which, as in that of many other contents of stories, resort is had to both plain matter-of-fact circumstances and to the whole gamut of peasant fancy and wisdom. There are tricks humorous and tricks malicious. There is the cruel practical joke, the mysterious supernatural tragedy, the downright cheat; even the lie direct is perpetrated by the Lady of Virtue (Silla Dai), who is held up to honour as the embodiment of all the virtues.

References to, and details of, ceremonies of all sorts are a necessary, and frequently a most valuable, form of folktale incident, but they do not require more than mere mention in such a discussion as this. In the Legends we are treated to many a most interesting and instructive description especially of marriage ceremonies, involving allusions to equally interesting and instructive notions about marriages generally. In fact, as regards marriages, and the betrothals which are their counterparts in India, a perusal of the Legends will take the reader over the whole subject: the beliefs, forms, ccremonies, customs and laws, and political uses; some of them throwing light on European customs of past and present times. In other directions also we are treated to allusions to, or descriptions real or fanciful of, such practical ceremonial matters as the adoption of girls, declaring an heir to the throne, regulating a Rajput huntingparty, the reception of guests. In sacerdotal or quasi-sacerdotal matters we have the ceremonies of divination by the breath, and initiatory rites into the sect of the LAlbegi scavengers, and into various sects of jogis and fagirs, of which 


\section{The Folklore in the Legends of the Panjab. 439}

the ear-boring ceremonies are the most prominent and of some importance, as they have led to the use of ear-rings of fixed sorts as signs of occupation or caste and to ear-boring customs among the women of various nations in the East as general prophylactics against evil.

In matters affecting the daily life of the people, there are the use of ashes as a sign of both grief and saintship, and other conventional modes of expressing sorrow, such as the breaking of bracelets and jewellery, and the ceremonies gone through by the newly-made widow. There are also various conventional ways of conveying specific and general challenge to combat, claiming inheritance to land, blackening the face and other strange methods of inflicting disgrace. Of the daily and domestic customs which are hardly to be distingushed from ceremonial observances, there are many instances; e.g., the quaint methods of showing that the occupant of a louse is " not at home," announcing a visitor, awakening a slumbering chief on an emergency, tying a knot to jog the memory, showing submission and making supplication. To show how the Legrends reflect the people and their ways, there is an interesting use made for story-telling purposes of the inveterate habit of village children of teasing hedgehogs.

Allusions to popular beliefs and the frequent introduction of incidents turning on them must of course be looked for. These open up so many questions of interest and debatable points, that it would only be unduly swelling this already too long category of folklore subjects, to do more here than just merely run over the recognised titles of some of those that occur in the Legends and have not been above classified, in order to bring them to notice, and to show how very wide is the net that is cast by this collection of tales for gathering in the flotsam of Indian folklore. Many are the beliefs relating to the animal world and their forms, of which the following are samples:-the origin of twisted and back. curved horns of various deer; the sacred, celestial, and 


\section{The Folklore in the Legends of the Panjab.}

marvellous characteristics of that favourite, the horse; the sacred and supernatural nature of the peacock and the swan; the capabilities of the dreaded scorpion. Beliefs relating to the heavenly bodies are necessarily legion, and those relating to eclipses and the moon and stars find a place here, as do also the worlds outside that which man inhabits, heaven and hell and their inhabitants, haris and such-like. The parts of the human body and their uses give rise to many beliefs, such as the correct foot to start with, the marks of hands and feet on rocks and other places, both natural and marvellous, the head and the shaving thereof. We have also most interesting references to the world-wide belief in a flood or deluge, clearly in one instance more or less indirectly based on the Biblical story. And lastly, there are many data for arriving at a clear notion of the peasant ideas of the Deity and the confusion of mind they are troubled with on the subject, owing to the intermixing of Hindu and Musalman teaching in so many parts of India.

Customs having their roots in popular beliefs are from their very nature, not only perpetually alluded to in the stories of the folk, but are a productive source of incidental narrations; $e . g$. , the aspect of the shrines as the remnant of sun-worship. Of these the old-world and universal idea of refuge, asylum, and sanctuary, as it is variously called, and as likely as not owing its inception and extension to sacerdotal pretensions and exclusiveness, is perhaps the most favoured in legend and folklore. In practical application it everywhere consisted of protection to strangers against their enemies, so long as they paid their way and only so long. The well-known Oriental conception of hospitality and its obligations is sanctuary pure and simple, both in theory and practice. Indeed, the Indian and Eastern notion of hospitality cannot be distinguished from sanctuary, and when the Pathan treats his enemy or a guest worth plundering to the best cheer in his power, gives him a fair start, and then prepares to try and murder or rob him, he 


\section{The Folklore in the Legends of the Panjab. $44^{\mathrm{I}}$}

is merely doing in his way what the old heathen Greek, or for that matter the medieval Christian priest, did in his, when he granted asylum or sanctuary to the fugitive or criminal only so long as he could pay for it, and made no sort of effort to shield him or obtain immunity for him when the payment ceased. All this is pithily brought out in a passage in the Legends. Raja Rasalu's faithless wife had successfully hidden her paramour, Raja Hodi, in her husband's house, but Rasalu's faithful parrot betrayed him, and then we read:- "Said the parrot: 'Slay not thy guest, he is as thy brother.' So Raja Rasalu and Hodi went together to the wilds, and there, wounded by an arrow, Raja Hodi was slain."

The very widespread custom, rooted in a superstitious belief that it brings ill-luck, of declining to refer to a husband by name is also mentioned in the Legends; while on the other hand the ancient royal prerogative of releasing prisoners, nowadays in civilised Europe attributed solely to kindliness and mercy, is given in the directest phraseology its right attribution of an act to insure good luck. That very ancient and widespread Oriental emblem of divine protection, the shade-giving umbrella, is repeatedly mentioned, as might be expected, in its degenerated form of a sign of royalty and thence of dignity generally.

Indian folktales end up usually in the most orthodox manner. The hero and heroine live happy ever afterwards after the Indian fashion, which I must remind European readers is not at all theirs, and the villain, male or female, comes to an untimely and well-deserved end. Poetical justice is thoroughly appreciated in the East, perhaps because for so many ages there has been so little of any other description. The interest here is chiefly in the forms that vengeance and punishment take as an indication of the popular notions on the subject. In the Legends and elsewhere punishments are all vindictive and cruel, most ingenious indeed in their cruelty; and torture is solely used as 


\section{$4+^{2}$ The Folklore in the Legends of the Panjab.}

a means of expressing vindictiveness. In resorting to it there is no other ulterior motive. Enemies are cut to pieces, buried and burnt alive, shot to death with arrows, buried up to the neck to starve, in company on occasion with thorns, scorpions, snakes, and so on. There is much personal triumph mixed with the vengeance. Enemies' skulls are mounted in silver as drinking cups, strangled bodies are exposed, graves of enemies are ploughed up and walked over by the conquering hero and heroine, the ashes of victims of burning alive are sent to their mothers, and an unchaste wife is tricked into eating her lover's heart by the injured husband. Callously cruel as all these proceedings are, they may, as every reader of Oriental history knows, be fairly termed mild when compared with many that must have often been within the actual personal knowledge of the peasantry of all parts and at all times, even the most recent.

The lengths to which sacerdotal vindictiveness has often gone in India, is indicated by the well-established custom of ceremonial suicide, self-immolation, and self-injury, in order to bring divine or supernatural wrath on an opponent or enemy. Debased as such a custom is in its nature and object, it has given rise to another equally well established and as noble as its prototype is execrable: the old and often exercised Rajput sakd or jauhar, which meant the voluntary suicide of the women of a palace, while the men went out to make the last wild sally when it was no longer possible to continue a defence.

With this, perhaps the noblest outcome of all of Indian superstition and belief, $I$ close my present remarks, in the hope that I have said enough to show that in the Legends of the Panjab we have displayed before us practically the whole machinery of popular Indian story-telling. Both the actors and their actions, so far as we have been able to regard them, have all shown themselves to be of the same descriptions, and to have the same characteristics as those in Indian folktales generally, whether purely narrative or 
PIATTE V'III.

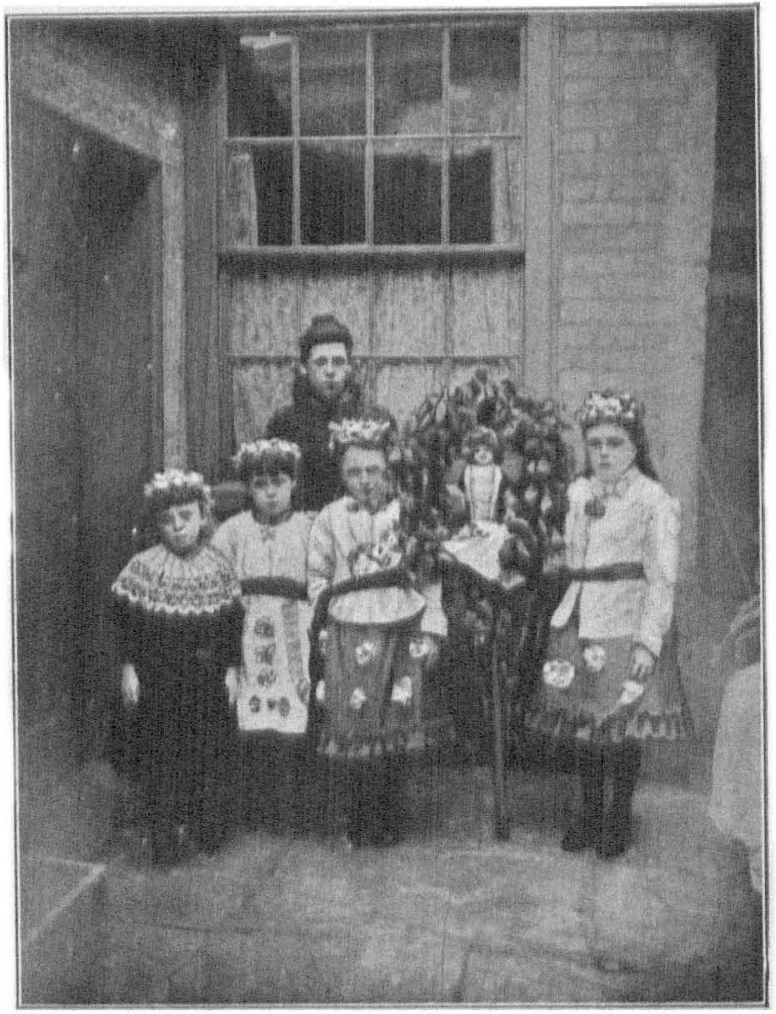

MAY LADIES, KING'S LYNN, 1894.

[Tis face page 443 . 


\section{The Folklore in the Legends of the Panjab. 443}

of set purpose connected with the hagiolatry or demonolatry of the people, I hope also that what has been laid before my readers has been sufficient to convince them that these Legends, if explored, will decisively and instructively show the value of studying them in detail to those who. would dig down to the roots of folklore anywhere in the world, and would learn something of the thoughts of the folk and of the trains of reasoning, which give form to the many apparently incomprehensible and unreasonable actions observable in the every-day life of the peasantry everywhere.

\section{WEDNESDAY, JUNE 21st, 1899.}

The President (Mr, E, Sidney Hartland) in the Chair.

THE minutes of the last Meeting were read and confirmed.

The election of Mr. G. Sneddon and Mrs. W. Beer as Members of the Society, and the withdrawal of the resignation of Miss Edith Mendham were announced.

The death of $\mathrm{Mr}$. W. Gore Marshall was also announced.

The Secretary, on behalf of Mr. William Whitelegge, exhibited a hornbook, the property of the late Canon Whitelegge, dating back to 1745 , and referred to in Tuer's History of the IIornbook.

The President exhibited some photographs of "May Ladies " at King's Lynn, taken by Dr. Plowright, President of the Norfolk and Norwich Naturalists' Society, the ist May, 1894.1

'By kind permission of Dr. Plowright and Mr. W. A. Nicholson, honorary secretary of the Norfolk and Norwich Naturalista' Society, one of the photo* graphs is here reproduced. Dr. Plowright'a account of the "May Ladies" at Lyan is as followa: "On the Ist of May, during the marning, sundry parties of children carry round the town garlands of flowers. The children, girls and boys, are dressed principally in white, with crowns of nowers on their heads and money-boxes in thelr hands. They are bare-headed, and their clothing is decorated with brightly-coloured calico, ribbons, or paper. The garlands are to us the most interesting. They are always constructed in 